\title{
Section 5 of the Voting Rights Act of 1965 After Boerne: The Beginning of the End of Preclearance?
}

\author{
Victor Andres Rodríguez†
}

\section{TABLE OF CONTENTS}

Introduction.

I The Importance and Impact of the Voting Rights Act and Section 5... 776

A. Why a Strong Voting Rights Act Was Necessary ..................... 776

B. The Role of Section 5 in Enforcing Voting Rights.................... 781

1I From Katzenbach to Boerne: The Court's Shifting View of

Congress's Constitutional Enforcement Power.................................. 784

A. Congressional Authority Affirmed: South Carolinav.

Katzenbach and Katzenbach v. Morgan ................................. 787

B. Congressional Authority Reconsidered: Boerne and its

Progeny

III Assessing Potential Challenges to the Constitutionality of Section

5: Now and in the Future............................................................. 794

A. Section 5 in Light of Boerne: An Analysis of Section 5's

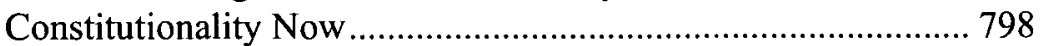

B. Reauthorization of Section 5............................................. 802

1. Responding to Constitutional Objections in the

Reauthorization Context

Copyright $(2003$ California Law Review, Inc. and author. California Law Review, Inc. (CLR) is a California nonprofit corporation. CLR and the authors are solely responsible for the eontent of their publications.

$\dagger \quad$ Skadden Fellow, Mexican-American Legal Defense and Educational Fund, October 2003October 2005; J.D. Candidate, School of Law, University of California, Berkeley (Boalt Hall), 2003; M.A., California State University, Long Beach, 2000; B.A., University of Southern California, 1997. 1 would like to thank Professor Kathryn Abrams for her guidance and expertise and Professor Ian HaneyLópez for his invaluable feedback and mentorship during my time at Boalt. I also want to thank Joaquín Avila and Steve Reyes for their input and suggestions, with speeial thanks to Joaquin for all that he has done to advance the cause of voting rights. I also truly appreciate the effort that many at the California Law Review put forth in making this a better piece (especially Heather Rosmarin) and the efforts by others to make California Law Review a better place (especially Gabriela Gallegos and Donna Maeda). Lastly, I would like to thank my family for their sacrifice and support and my fiancée, Jodi Swick-for whom I am eternally grateful to Boalt for introducing me. 
2. Ongoing Need for Strong Voting Rights Protections: The Substantive Argument for Reauthorization

3. Public Reliance: The Symbolic Argument for Reauthorization

C. Section 5's Constitutionality After Reauthorization

1. Applying Boerne's Congruence-and-Proportionality Test to the Reauthorization of Section 5 814

2. Constitutional Dialogue Between Congress and the Court .. 816

3. Stare Decisis: Reliance of Minority Voters on the Protection of Their Rights

Conclusion 


\title{
Section 5 of the Voting Rights Act of 1965 After Boerne: The Beginning of the End of Preclearance?
}

\author{
Victor Andres Rodríguez
}

Congress enacted the Voting Rights Act of 1965 (the "Act") to combat pervasive and systemic discrimination against minority voters. Section 5 of the Act requires state and local jurisdictions with a history of voting discrimination to submit any new changes in voting laws or procedures to the U.S. Attorney General for approval before implementing them. This requirement, known as "preclearance," is the most important provision of what has been described as the most effective civil rights legislation ever adopted. However, Section 5 's future is in doubt for several reasons. First, the Supreme Court has, in a recent line of cases starting with City of Boerne v. Flores, 521 U.S. 507 (1997), limited the scope of Congress's power to enact civil rights legislation. Second, Section 5 is due to expire in 2007. This Comment assesses the potential challenges to Section 5 's constitutionality in light of the Court's recent decisions and discusses the provision's prospects for reauthorization in 2007. Specifically, the Comment addresses the federalism and separation-of-powers concerns that were raised when Section 5 was initially enacted and that have recently gained sway with the Court. The Comment concludes that Section 5, if challenged today, would meet the Court's test for civil rights legislation. The Comment also concludes that Section 5 should be reauthorized and would be held constitutional if challenged after reauthorization.

\section{INTRODUCTION}

In 1965 Congress passed the Voting Rights Act (the "Act")' to enforce rights granted to minority voters almost a century before by the Fourteenth and Fifteenth Amendments. Although the Fourteenth Amendment prohibited the states from denying equal protection of the laws ${ }^{2}$ and thc Fifteenth Amendment prohibited the states from denying the

1. Voting Rights Act of 1965,42 U.S.C. $\$ 1973(2000)$.

2. U.S. ConsT. amend. XIV, $\$ 1$ I. It provides:

All persons born or naturalized in the United States and subject to the jurisdiction thereof, are citizens of the United States and of the State wherein they reside. No State shall make or enforce any law which shall abridge the privileges or immunities of citizens of the United 
right to vote on account of race or color, ${ }^{3}$ Blacks and other minorities continued to face de facto, and even de jure, disenfranchisement in many states well into the twentieth century. ${ }^{4}$ The variety of means utilized by state and local officials, primarily in the South, to keep Blacks from the polls was limited only by those officials' imaginations. ${ }^{5}$ This unwillingness to allow Blacks a voice at the ballot box set the stage for the passage of the Act. ${ }^{6}$

The Act created an unprecedented arsenal of weapons to force Southern compliance with laws granting Blacks the right to vote. Compared to other congressional corrective measures, the Act was, and remains, astonishingly forceful in its remedies and broad in its coverage. ${ }^{7}$ Among the potent remedies enacted was Section 5, which imposes a "preclearance" requirement on certain state and local jurisdictions. Specifically, Section 5 requires covered jurisdictions-those with a history of race-based voting discrimination and low voter registration-to submit all proposed changes to voting qualifications and procedures to the federal government for approval before those changes can go into effect. ${ }^{8}$

States; nor shall any State deprive any person of life, liberty, or property, without due process of law; nor deny to any person within its jurisdiction the equal protection of the laws. Id.

3. U.S. ConsT. amend. XV, $\$ 1$. ("The right of citizens of the United States to vote shal1 not be denied or abridged by the United States or by any State on account of race, color, or previous condition of scrvitude.").

4. See generally Alexander Keyssar, The Right to Vote: The Contested History of Democracy in THE UNITED States 264 (2000).

5. See Keith J. Bybie, Mistaken 1dentity: The Supreme Court and the Politics of MinORITY REPRESENTATION 15 (1998) (discussing some of the ways used by polling officials to deny Blacks a votc); see also infra Part l.A.

6. Id. at 16 .

7. See, e.g., South Carolina v. Katzenbach, 383 U.S. 301, 334 (1966) (discussing the scope of the Act's provisions and the "exceptional conditions" justifying them).

8. $\quad 42$ U.S.C. $\$ 1973 \mathrm{c}(2000)$. Section 5 provides:

Whenevcr a [covered] State or political subdivision ... shall enact or seek to administer any voting qualification or prerequisite to voting, or standard, practice, or procedure with respect to voting different from that in force or effect on [one of the three statutory triggering dates] . . such State or subdivision may institute an action in the United States District Court for the District of Columbia for a declaratory judgment that such qualification, prerequisite, standard, practice, or procedure does not have the purpose and will not have the effect of denying or abridging the right to vote on account of race or color ... and unless and until the court enters sueh judgment no person shall be denied the right to vote for failure to eomply with such qualification, prerequisite, standard, practice, or procedure: Provided, That such qualification, prerequisite, standard, practice, or procedure may be enforced without such proceeding if the qualification, prerequisite, standard, practice, or procedure has been submitted by the chief legal officer or other appropriate official of such State or subdivision to the Attorney General [of the United States] and the Attorney General has not interposed an objection within sixty days after such submission, or upon good cause shown, to facilitate an expedited approval within sixty days after such submission, the Attorney General has affirmatively indicated that such objection will not be made. Neither an affirmative indication by the Attorney General that no objection will be made, nor the Attorney General's failure to object, nor a declaratory judgment entered under this section shall bar a subsequent action to enjoin enforcement of such qualification, prerequisite, standard, practiee, or procedure. In the event the Attorney Gcneral affirmatively indicates that no objection will be made within the sixty-day period following reccipt of a submission, the Attorney General may reserve the right to reexamine the submission if additional information comes to his attention during the remainder of the sixty-day period which would otherwise require objection in accordance 
At the time of passage, both opponents and proponents of the Act understood that Section 5's preclearance provisions would fundamentally and radically shift the balancc of power from the states to the federal government with respect to voting rights. ${ }^{9}$ According to its detractors, Section 5 threatened to reduce states to "conquered provinces," forcing them to "beg federal authorities to approve their policies." specifically and the Act in general as "the most effective civil rights legislation ever passed in this country." 11 They considered Section 5 to be among the most formidable of the Act's provisions and its preclearance requirement to be essential to prevent backsliding on the part of the jurisdictions with the worst history of racial discrimination. ${ }^{12}$

Responding to the concern about the intrusion into states' rights, Congress included termination dates in several of the Act's provisions, including Section $5 .^{13}$ Initially set to expire in 1970 , Section 5 was reauthorized and extended by Congress first for five years (to 1975) and then for seven (to 1982). In 1982, Congress extended Section 5 for another twentyfive years. ${ }^{14}$ Accordingly, Section 5 is due to expire in 2007 unless Congress chooses to extend the provision again. ${ }^{15}$

Since its enactment in 1965 , Section 5 has withstood repeated legal challenges. Critics have raised two main objections to its constitutionality. Initially, critics charged that it violated federalism by infringing on states' rights; later, critics charged that it violated the separation-of-powers doctrine by usurping the judiciary's power to determine what is unconstitutional. ${ }^{16}$ The Supreme Court considered and rejected the federalism argument in 1966, when it upheld Section 5 in South Carolina $v$. Katzenbach. ${ }^{17}$ Since Katzenbach, the Court has consistently ruled that a long history of racial discrimination in voting justifies a certain degree of federal intrusion into statc and local affairs. ${ }^{18}$

with this section. Any action under this section shall be heard and determined by a court of three judges in accordance with the provisions of section 2284 of title 28 and any appeal shall lie to the Supreme Court. $I d$.

9. BYBEE, supra note 5 , at 85 .

10. Katzenbach, 383 U.S. at 358-60 (Black, J., dissenting).

11. Extension of the Voting Rights Act, 1975: Hearings on H.R. 939, H.R. 2148, H.R. 3247, and H.R. $350 I$ Before the Subcomm. on Civil and Constitutional Rights of the House Comm. of the Judiciary, 94th Cong., 1 Sess., Pt. 1, at 1 (1975) (statement of Don Edwards, Subcomm. Chairman).

12. BYBEE, supra note 5, at 85.

13. U.S. Dep't of Justice, Civil Rights Div., Voting Section, Introduction to Section 5 Preclearance, at http://www.usdoj.gov/crt/voting/sec_5/about.htm (last revised Dec. 13, 2002) [hereinafter Section 5 Preclearance].

14. Id.

15. Id.

16. See infra Part 11 for analysis of these two objections and the relevant case law.

17. 383 U.S. 301 (1966).

18. See, e.g., Lopez v. Monterey County, 525 U.S. 266, 284-85 (1999), City of Rome v. United States, 446 U.S. 156, 179-80 (1980). 
In the 1960 s, the Court also considered and rejected the separation-ofpowers argument as applied to the Act. ${ }^{19}$ However, recent rulings indicate that the current Court may reconsider this position. In a series of Fourteenth Amendment cases beginning with City of Boerne v. Flores in 1997, the Court has demonstrated that it is taking the separation-of-powers argument quite seriously in reviewing and striking down statutes authorized under Congress's Fourteenth Amendment enforcement power. ${ }^{20}$ it is important to note that the Court has always regarded Congress's enforcement powers under the Fourteenth and Fifteenth Amendments to be coextensive. ${ }^{21}$ Hence, the recently imposed limitations on Congress's Fourteenth Amendment enforcement power extend also to its Fifteenth Amendment enforcement power. Therefore, there is reason to be concerned that the constitutional basis for broad remedial measures like Section 5, which is authorized under Congress's Fifteenth Amendment enforcement power, is newly vulnerable to attack.

In the Boerne line of cases, the Court limited Congress's authority to enact broad remedies for equal protection violations. The Court's concern was that if the remedies were too broad, Congress-rather than the Courtwould be deciding the substantive contours of the Fourteenth Amendment. The Boerne Court articulated the principle that Congress has the power to "enforce," not the power to "determine" what constitutes a constitutional violation. ${ }^{22}$ The power to determine constitutional violations rests with the judiciary, and Congress cannot infringe upon that power without violating the separation-of-powers doctrine. The Boerne Court established a "congruence-and-proportionality test" to distinguish between permissible remedial action and impermissible substantive action. ${ }^{23}$

19. Katzenbach v. Morgan, 384 U.S. 641 (1966); see infra text accompanying notes 138-42.

20. Recent jurisprudence limiting Fourteenth Amendment congressional enforccment power includes: Alexander v. Sandoval, 532 U.S. 275 (2001) (limiting Title VI of the Civil Rights Act of 1964 to only include intentional discrimination and to cxclude a private right of action); $B d$. of Trs. $v$. Garrett, 531 U.S. 356 (2001) (limiting remedies under the Americans with Disabilities Act); United States v. Morrison, 529 U.S. 598 (2000) (striking down provisions of the Violence Against Women Act); and City of Boerne v. Flores, 521 U.S. 507 (1997) (striking down the Religious Freedom Restoration Act). In addition, there have been Court opinions casting specific portions of the Voting Rights Act ("Act") into some doubt. See, e.g., Rcno v. Bossier Parish Sch. Bd., 520 U.S. 471, 485 (1997) (holding that Section 5 preclearance may not be withheld on the basis of a Section 2 violation); Miller v. Johnson, 515 U.S. 900 (1995) (holding that a redistricting plan to maximize the number of majority-minority districts violated the Equal Protection Clause of the Fourteenth Amendment); Holder v. Hall, 512 U.S. 874 (1974) (holding that Section 2 does not support a challenge to the size of a county commission).

21. Lopez, 525 U.S. at 294 n.6.

22. City of Boerne, 521 U.S. at 519.

23. Id. at 520 ("There must be a congruence and proportionality between the injury to be prevented or remedied and the means adopted to that end."). For a detailed discussion, see infra Part II.B (describing the test), Part III.A (applying the test to Section 5), and Part 111.C (considering the constitutionality of Section 5 after reauthorization). 
To date, the Act and Section 5 have escaped direct challenge under the new line of Fourteenth Amendment cases. In fact, in Boerne and several related cases, the Court cited the Act as an example of permissible use of congressional enforcement power. ${ }^{24}$ Despite this reassuring language, several scholars have suggested that the Court's recent jurisprudence may signal the Court's willingness to rethink its position regarding the basis of the Act's constitutionality. ${ }^{25}$ Indeed, at least one member of the Court has explicitly indicated his willingness to limit the scope of Section $5 .^{26}$

Section 5's vulnerability is likely to increase further if Congress reauthorizes and extends the provision in 2007. The time limitation on Section 5 has been one of the main factors distinguishing it from statutory provisions that the Court has recently disapproved. ${ }^{27}$ Opponents of Section 5 could argue that Congress's repeated extension of Section 5 renders the time limitation less meaningful.

To assess current and potential threats to the continued validity of Section 5, this Comment analyzes the provision's constitutionality in light of recent cases in which the Court has seriously limited congressional authority to enact broad remedies for equal protection violations. ${ }^{28}$ Part I describes the Act's purpose, the events leading to its passage, and the importance of its provisions, particularly Section 5 , in protecting racial minorities' voting rights. Part II examines the reasoning of early Court decisions upholding the Act as well as recent Court decisions limiting Congress's constitutional enforcement authority. Part III assesses three contexts in which Section 5's constitutionality may be challenged: during the years leading to reauthorization in 2007; during Congress's reauthorization debate; and after reauthorization.

Part III.A analyzes the Act and Section 5 in the context of recent cases and concludes that a challenge in the near future should fail given the

24. See, e.g., Bd. of Tr. v. Garrett, 531 U.S. 356, $373-74$ (2001); Morrison, 529 U.S. at 626-27; City of Boerne, 521 U.S. at 518.

25. See, e.g., Pamela S. Karlan, Two Section Twos and Two Section Fives: Voting Rights and Remedies Afier Flores, 39 WM. \& MARY L. REv. 725, 730-31 (1998) (arguing that the majority's standard in Boerne could signify a constitutional time limit on the validity of the Act); Douglas Laycock, Conceptual Gulfs in City of Boerne v. Flores, 39 WM. \& MARY L. Rev. 743, 748-49 (1998) (arguing that the Boerne decision did not explain how the Act meets the more stringent standard announced by the Court); John Matthew Guard, "Impotent Figureheads"? State Sovereignty, Federalism, and the Constitutionality of Section 2 of the Voting Rights Act After Lopez v. Monterey County and City of Boerne v. Flores, 74 TuL. L. Rev. 329, 330 (1999) (arguing that the Court's voting rights opinions are in conflict with its opinions regarding the limits on Congress's Fourteenth Amendment enforcement power).

26. See Lopez v. Monterey County, 525 U.S. 266, 293-98 (1999) (Thomas, J., dissenting). In his Lopez dissent, Justice Thomas termed Section 5's obligations "drastic" and "troubling," and suggested that he would take a limited view of the provision's scope and application. Id. at 293.

27. See infra Part 111.A (analyzing how the Court has distinguished the Act from other equal protection statutes).

28. See supra note 20 
Court's endorsement of the Act as an example of permissible legislation that passes Boerne's congruence-and-proportionality test. ${ }^{29}$ Part III.B sets forth a three-fold case for reauthorizing Section 5 in 2007: it discusses and responds to potential congressional objections, it assesses the ongoing need to protect minorities' voting rights, and it highlights the public's reliance on the Act. Finally, Part III.C discusses the legal challenges to the Act's constitutionality that might arise after it is reauthorized. Compared to a challenge brought today, a post-authorization challenge poses a far greater threat to the Act, and Section 5 in particular. The Comment argues that the Court should continue to uphold the constitutionality of the Act and Section 5 on three grounds. First, a post-reauthorization Section 5 will still pass muster under Boerne's congruence-and-proportionality test. Second, there has been a unique interbranch dialogue between Congress and the Court that has repeatedly affirmed the constitutionality of Section 5 as a broad remedy ${ }^{30}$ Third, under the doctrine of stare decisis, as explicated in Planned Parenthood v. Casey, ${ }^{31}$ the Court should adhere to its numerous precedents upholding the constitutionality of Section 5.

\section{I \\ THE IMPORTANCE AND IMPACT OF THE VOTING RightS ACT AND SECTION 5 \\ A. Why a Strong Voting Rights Act Was Necessary}

Prior to the Act, disenfranchisement of Black voters in the South was widespread and systemic. ${ }^{32}$ Despite the passage of the Fourteenth and Fifteenth Amendments almost a century earlier ${ }^{33}$ Southern legislators' control of Congress had insured that thcse provisions were not substantially enforced. ${ }^{34}$ Congressional inaction allowed state and local governments in the South to block Blacks' enfranchisement by engaging in various discriminatory practices. ${ }^{35}$

29. City of Boerne, 521 U.S. at 520 . The Court has pointed to the Act as an example of a broad congressional remedy that would pass the congruence-and-proportionality test in several decisions, including: Garrett, 531 U.S. at 373-74; Morrison, 529 U.S. at 626-27; City of Boerne, 521 U.S. at 518.

30. See Robert C. Post \& Reva B. Siegel, Equal Protection by Law: Federal Antidiscrimination Legislation After Morrison and Kimel, 110 YALE L.J. 441, 522 (2000).

31. 505 U.S. 833, 854-69 (1992).

32. U.S. Dep't of Justicc, Civil Rights Div., Voting Section, Introduction to Federal Voting Rights Laws, at http://www.usdoj.gov/crt/voting/intro/intro.htm (last revised Fcb. 11, 2000) [hereinafter Federal Voting Rights Laws].

33. See U.S. Const. amend. XIV-XV.

34. Samuel 1ssacharoff et al, The law of Democracy: Legal Structure of the Political. Process 546 (2d ed. 2001) [hereinafter Law of Democracy].

35. See South Carolina v. Katzenbach, 383 U.S. 301, 308-09 (1966) (summarizing the majority reports of the House and Senate Committees documenting these practices). 
Among the most important forms of structural discrimination were: registration barriers such as the poll tax, grandfather clauses, and literacy tests (to prevent Blacks from voting); White primaries (to reduce Blacks to the role of ratifying White-approved candidates); gerrymandering (to concentrate Blacks into few districts); annexation (to alter the composition of the electorate); at-large voting (to submerge minority populations); and the redesign of governing bodies (to reduce, for example, the total number of elected offices). ${ }^{36}$

Although government-sponsored discrimination against Black voters was widespread, not until 1957 did Congress create the Civil Rights Division of the Department of Justice (the "DOJ"). ${ }^{37}$ The Civil Rights Act of $1960^{38}$ then empowered this division to bring suits on behalf of citizens denied the right to vote on account of race. ${ }^{39}$ Although these enforcement suits represented a step forward, they were also incredibly time consuming and inefficient. The DOJ was forced to prosecute suits county by county, often spending thousands of hours combing through records to prepare a single case. ${ }^{40}$ Such efforts were undermined by state and local officials determined to thwart enfranchisement. ${ }^{41}$ Local officials "lost" records, resigned their positions (to undermine the force of any injunctions entered against them), left registrar positions vacant, and purged voter rolls of Blacks. $^{42}$

While the DOJ's legal efforts continued, new grassroots citizen movements sought to build popular pressure on Southern governors and local officials. ${ }^{43}$ As part of these grassroots campaigns, Black citizens and their supporters marched, rallied, boycotted, petitioned, and sued. ${ }^{44} \mathrm{Na}-$ tional and regional organizations, like the National Association for the Advancement of Colored People, unions, and the newly formed Southern Christian Leadership Conference, led complementary efforts to advocate for the enfranchisement of Blacks. ${ }^{45}$

Black citizens and their supporters frequently met with violent resistance from Southern citizens and police officers. On many occasions,

36. BYBEE, supra note 5, at 15. This list of "structural" efforts does not include less formal but equally effective tactics of intimidation. There were numerous reports of threatened or actual violence in response to Blacks trying to assert their right to vote. $I d$, at 14-15.

37. Civil Rights Act of 1957, Pub. L. No. 85-315, § 101, 71 Stat. 634.

38. Civil Rights Act of 1960, Pub. L. No. 86-449, 74 Stat. 86.

39. J. Morgan Kousser, Colorblind injustice: Minority Voting Rights and the UNDOING OF THE SECOND RECONSTRUCTION 54 (1999).

40. Katzenbach, 383 U.S. at 314 (noting that the DOJ's efforts were largely inefficient and ineffective).

41. LAW OF DEMOCRACY, supra note 34 , at 546.

42. Id.

43. KEYSSAR, supra note 4 , at 258.

44. Id.

45. Id. 
peaceful marchers were faced with brutality that left some dead. ${ }^{46}$ In one account:

Jimmie Lee Jackson was a young black farmer who for nearly three years had tried unsuccessfully to register to vote in Alabama. On February 18, 1965, Jimmie Lee joined over two hundred marchers who exited Mount Zion church in the small town of Marion, Alabama to begin a night march for voting rights. The marchers walked less than a block when they were stopped by state troopers who ordered them to disperse. The marchers halted and some of them knelt down to pray. The troopers responded by attacking the marchers with clubs, causing the marchers to panic and disperse. While Jimmie Lee sought refuge in a neighboring restaurant with his mother, he saw his grandfather enter bleeding and badly beaten. Jimmie Lee tried to leave the restaurant and take his grandfather to the hospital, but he was pushed back in by troopers swinging their clubs and marchers who were fleeing their wrath. When Jimmie Lee observed one trooper hit his mother, he ran to protect her. A trooper hit him in the face with a club and threw him into a cigarette machine. As Jimmie Lee struggled to get up, another trooper pulled out a pistol and shot him in the stomach. Jimmie Lee died eight days later. ${ }^{47}$

In another effort to register new voters, organizers arrived in Selma, Alabama in $1965 .{ }^{48}$ They picked Selma in part because they knew the sheriff was prone to the kind of overreaction that the national media would cover, and they wanted to garner national support for their cause. ${ }^{49}$ On March 7, 1965, these voting rights supporters confronted state troopers, sheriff's deputies, and "possemen" 50 on horseback. ${ }^{51}$ Voting rights supporters tried to march from Selma to Montgomery, the state capital, to present then-Governor George Wallace with a list of grievances. ${ }^{52}$ They were stopped on the Edmund Pettus Bridge in Selma by troopers and deputies who, in front of television cameras, proceeded to attack the more than 500 demonstrators by firing tear gas into the crowd, charging the marchers, and

46. Id. at $258-59$.

47. James Thomas Tucker, Affirmative Action and Misrepresentation: Part I --Reelaiming the Civil Rights Vision of the Right to Vote, 43 How. L.J. 343, 343-44 (2000).

48. LAW OF DEMOCRACY, supra note 34, at 547.

49. See Michael J. Klarman, Brown, Racial Change and the Civil Rights Movement, 80 VA. L. REV. 7, 147.49 (1994).

50. "Possemen" were auxiliary deputies under the control of the sheriff who engaged in "harassment, intimidation, coercion, threatening conduct, and, sometimes, brutal mistreatment" of protestors. Williams v. Wallace, 240 F. Supp. 100, 104 (M.D. Ala. 1965).

51. Law OF Democracy, supra note 34 , at 547.

52. Id. 
beating them with clubs and whips while the onlooking crowd of. Whites cheered. ${ }^{53}$

Until this violence exploded into the national spotlight, the chances of passing a voting rights bill with any teeth were slim. ${ }^{54}$ President Johnson faced opposition from within his own party: Southern Democrats were not interested in a civil rights bill that would be unpopular with constituents and jeopardize their political careers. ${ }^{55}$ However, after the events in Selma, which sparked national outrage, and the "Freedom Summers," highlighted increasing support for civil rights, President Johnson felt the tide turning. ${ }^{57} \mathrm{He}$ ordered Attorney General Katzenbach to "prepare the 'goddamnedest toughest' voting-rights bill possible." 58 Before a national television audience, President Johnson addressed a special joint session of Congress:

At times history and fate meet at a single time in a single place to shape a turning point in man's unending search for freedom. So it was at Lexington and Concord. So it was a century ago at Appomattox. So it was last week in Selma, Alabama.... Every device of which human ingenuity is capable has been used to deny this right. The Negro citizen may go to register only to be told that the day is wrong, or the hour is late, or the official in charge is absent. ... For the fact is that the only way to pass these barriers is to show a white skin. Experience has clcarly shown that the existing process of law cannot overcome systematic and ingenious discrimination. No law that we now have on the books ... can ensure the right to vote when local officials are determined to deny it.... This time, on this issue, there must be no delay, no hesitation and no compromise with our purpose.... We have already waited a hundred years and more, and the time for waiting is gone. ${ }^{59}$

The resulting bill contemplated an unprecedented extcnsion of federal authority into local political practices. ${ }^{60}$

53. Laughlin McDonald, The 1982 Extension of Section 5 of the Voting Rights Act of 1965: The Contimued Need For Preclearance, 51 TenN. L. Rev. 1, 25 (1983).

54. ByBEE, supra note 5, at 16.

55. Id.

56. "Freedom Summers" rcfer to the efforts to register Black voters in 1964 and 1965. Alvin Bronstein, Represcming the Powerless: Lawyers Can Make a Difference, 49 ME. L. REv. 1, 4 (1997) ("In 1964, you may remember that various national eivil rights organizations announced a 'Freedom Summer.' They were inviting a few thousand college students from around the country to eome to Mississippi, Alabama, and Louisiana to help register blaek eitizens, teach in Freedom Schools, and, just by their presencc, show some solidarity with the local folks who try to make a difference in their lives.”).

57. ByвеE, supra note 5, at 16.

58. Id.

59. Lyndon B. Johnson, Special Message to the Congress: The American Promise, (Mar. 15, 1965), in 107 PUB. PAPERS 281, $281-84$.

60. BYвEE, supra note 5, at 16. 
Despite Southern objections that the bill was an unconstitutional violation of federalism, Congress passed the Act complete with the most aggressive steps ever taken to ensure the protection of Blacks' right to vote. ${ }^{61}$ Section $2^{62}$ of the Act prohibited any voting qualification or prerequisite to voting, or standard, practice, or procedure that denied or abridged the right to vote on the basis of race or color. ${ }^{63}$ Section 4 contained a "trigger" that automatically suspended devices used in certain jurisdictions ${ }^{64}$ to deny the right to vote and prohibited the use of literacy tests in the entire country. ${ }^{65}$

61. Federal Voting Rights Laws, supra note 32.

62. Section 2 of the Act poses many of the same issues presented by Section 5. However, a full discussion of the important role that Section 2 has played, and continues to play, in voting rights litigation is beyond the scope of this Comment.

63. 42 U.S.C. $§ 1973(2000)$. Section 2 provides:

Denial or abridgement of right to vote on account of race or color through voting qualifications or prerequisites; establishment of violation (a) No voting qualification or prerequisite to voting or standard, practicc, or procedure shall be imposed or applied by any State or political subdivision in a manner which results in a denial or abridgement of the right of any citizen of the United States to vote on account of race or color ... (b) A violation of subseetion (a) of this section is established if, based on the totality of circumstances, it is shown that the political processes leading to nomination or election in the State or political subdivision are not equally open to partieipation by members of a class of citizens proteeted by subsection (a) of this scetion in that its members have less opportunity than other members of the electorate to participate in the political proccss and to elect representatives of their choice. The extent to which inembers of a protected class have been elected to office in the State or political subdivision is one circunstance which may be eonsidered: Provided, That nothing in this section establishes a right to have members of a protected class elected in numbers equal to their proportion in the population.

64. Id. $\S 1973 \mathrm{~b}$. Covered jurisdictions ineluded all states and counties where fewer than $50 \%$ of all adults had gone to the polls in 1964. U.S. Dep't of Justice, Civil Rights Div., Voting Section, Section 5 Requirements, at http://www.usdoj.gov/crt/voting/sec_5/types.htm (last revised Feb. 11, 2000) [hereinafter Section 5 Requirements].

65. 42 U.S.C. $\S 1973 b$ (2000). Section 4 provides:

(a) Action by State or political subdivision for declaratory judgment of no denial or abridgement; three-judge district court; appeal to Supreme Court; retention of jurisdiction by three-judge court.

(1) To assure that the right of citizens of the Unitcd States to vote is not denied or abridged on account of race or color, no citizen shall be denied the right to vote in any Fedcral, State, or local election because of his failure to coinply with any test or device in any [covered] State ... or in any political subdivision of such State ... unless the United States District Court for the District of Columbia issucs a declaratory judgment under this section. A declaratory judgment under this section shall issue only if such court determines that during the ten years preceding the filing of the action, and during the pendeney of such action-

(A) no such test or device has been used within such Statc or political subdivision for the purpose or with the effect of denying or abridging the right to vote on account of race or color ...;

(B) no final judgment of any court of the United States, other than the denial of declaratory judgment under this section, has determined that denials or abridgements of the right to vote on account of race or color have oceurred anywhere in the territory of sueh State or political subdivision ....;

(D) such State or political subdivision and all governmental units within its territory have eomplied with section $1973 \mathrm{c}$ of this title, including eompliance with the requirement that no change covered by section $1973 \mathrm{c}$ of this title has been enforced without preclearance under seetion 1973c, and have repealed all changes covered by section $1973 \mathrm{c}$ of this title to which the Attorney General has suecessfully objected or as to which the Unitcd States District Court for the District of Columbia has denicd a declaratory judgment; 
This provision is particularly notable because the Court had earlier ruled that literacy tests did not facially violate the Fifteenth Amendment. ${ }^{66} \mathrm{Sec}-$ tion 5 required covered jurisdictions to submit any changes in voting laws or procedures to the DOJ for approval before implementing them. The provision worked to prevent jurisdictions with histories of voting discrimination from instituting new voting changes in an effort to subvert the Act. ${ }^{67}$ Section $6^{68}$ authorized the appointment of federal examiners to go into the South to register voters and observe registration practices. ${ }^{69}$

\section{B. The Role of Section 5 in Enforcing Voting Rights}

The Act's impact was immediatc and dramatic:

(E) the Attorney General has not interposed any objection (that has not been overturned by a final judgment of a court), and no declaratory judgment has been denied under section 1973c of this title, with respect to any submission by or on behalf of the plaintiff or any governmental unit within its territory under section 1973e of this title, and no such submissions or declaratory judgment actions are pending; and

(F) such State or political subdivision and all governmental units within its territory-

(i) have eliminated voting procedures and methods of election which inhibit or dilute equal access to the electoral process;

(ii) have engaged in constructive efforts to eliminate intimidation and harassment of persons exercising rights protected under Subchapters l-A to l-C of this chapter; and

(iii) have engaged in other constructive efforts, such as expanded opportunity for convenient registration and voting for every person of voting age and the appointment of minority persons as election officials throughout the jurisdiction and at all stages of the election and registration process.

(2) To assist the court in determining whether to issue a declaratory judgment under this subsection, the plaintiff shall present evidence of minority participation, ineluding evidence of the levels of minority group registration and voting, changes in such levels over time, and disparities betwcen minority-group and non-minority-group participation. Id.

66. Lassiter v. Northampton County Bd. of Elections, 360 U.S. 45 (1959). By adopting this provision, Congress had used its Fifteenth Amendment enforcement power to attack a practice that the Court did not consider unconstitutional. This disconnect between what the Court and Congress were prepared to do forcshadowed the conflict that arose bctwcen the Court and Congress forty years later over the scope of Congress's enforcement power.

67. See supra note 8 and accompanying text.

68. 42 U.S.C. $\$ 1973 \mathrm{~d}(2000)$. Section 6 provides:

Whonever (a) a court has authorized the appointment of examiners ... or (b) unless a declaratory judgment has been rendered ... the Attorney Gcneral ccrtifies with respect to any [covered] political subdivision...that (1) he has received complaints in writing from twenty or more residents of such political subdivision alleging that they have bcen denied the right to vote under color of law on account of race or color ... and that he believes such complaints to be meritorious, or (2) that in his judgment (considering, among other factors, whether the ratio of nonwhite persons to white persons registered to vote within such subdivision appears to him to be reasonably attributable to violations of the fourteenth or fifteenth amendment or whether substantial evidence exists that bona fide efforts are being made within such subdivision to comply with the fourteenth or fifteenth amendment), the appointment of examiners is otherwisc necessary to enforce the guarantees of the fourteenth or fifteenth amendment, the Director of the Office of Pcrsonnel Management shall appoint as many examincrs for such subdivision as the Director may deem appropriate to prepare and maintain lists of persons eligible to vote in Federal, State, and local elections. . . Examiners and hearing officers shall have thc power to administer oaths.

69. See Kousser, supra note 39, at 55 (cxplaining that Section 6 would allow the appointment of fedcral voting registrars if local registrars continued to discriminate). 
Within a few months of the bill's passage, the Justice Department dispatched examiners to more than thirty counties in four states; scores of thousands of blacks were registered by the examiners, while many more were enrolled by local registrars who accepted the law's dictates to avoid federal oversight. In Mississippi, black registration went from less than 10 percent in 1964 to almost 60 percent in 1968; in Alabama, the figure rose from 24 percent to 57 percent. In the region as a whole, roughly a million new voters were registered within a few years after the bill became law, bringing African-American registration to a record 62 percent. $^{70}$

The vast majority of the Act's initial impact was due to Sections 2, 4, and $6{ }^{71}$ Despite its expansive language, Section 5 was initially underutilized. Indeed, in the first five years after the Act's passage (1965-1969), only 323 Section 5 changes were submitted to the Attorney General for review. ${ }^{72} \ln$ the next five years (1970-1974), only. 4,153 changes were submitted. ${ }^{73}$ Despite its humble beginnings, however, Section 5 has assumed a significant and central position in the voting rights enforcement scheme. As shown in Figure 1, the number of submissions increased dramatically in the 1980s and 1990s. Almost 50,000 changes have been submitted in the three most recent years on record (2000-2002), a number that exceeds the total submitted in the first fifteen years of the Act's life. ${ }^{74}$

\section{Figure 1: Section 5 Changes Submitted by Year ${ }^{75}$}

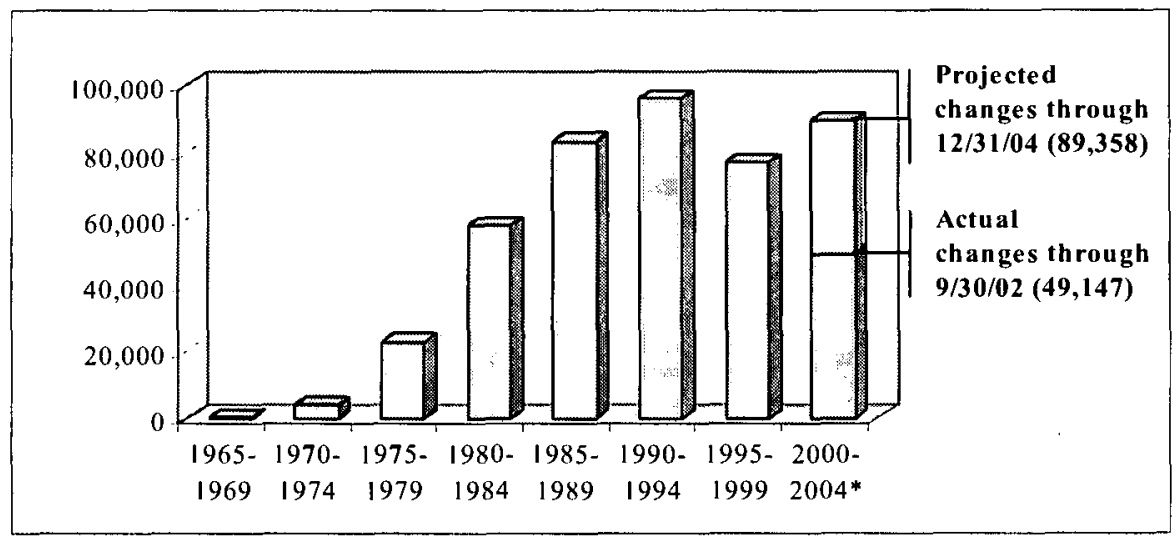

70. KEYSSAR, stupra note 4, at 264.

71. Id.

72. U.S. Dep't of Justice, Civil Rights Div., Voting Section, Section 5 Changes by Type and Year, at http:/www.usdoj.gov/crt/voting/sec_5/changes.htm (last revised Jan. 22, 2003) [hereinafter Section 5 Changes].

73. Id. Thesc numbers are insignificant when compared to the over 83,000 changes reviewed from 1985 to 1989 , the over 95,000 received from 1990 to 1994 , or the over 76,000 from 1995 to 1999.

74. $I d$.

75. Within Figure 1, the projected number of changes through the end of 2004 is only intended to demonstrate that the number of submissions to the DOJ remains very high (as does, therefore, the potential for mischief), and does not make a claim as to the general trend of submissions. 
Section 5 of the Act now stands as one of the most potent remedies, not just in voting rights jurisprudence, but in all of civil rights law. ${ }^{76}$ Although Section 5 was underutilized in the early days after the Act's passage, the extent of what the DOJ could aecomplish with it soon became clear. In 1969, the Court in Allen v. Board of Elections endorsed a broad application of Section $5 .{ }^{77}$ In Allen, the Court was concerned by continued Southern resistance to giving Blacks a meaningful vote. The state government was engaging in gerrymandering and other structural strategies to minimize the value and weight of the Black vote as much as possible. ${ }^{78}$ Rejecting the argument that the Act did not apply because Blacks were technically allowed to vote, the Court read Section 5 broadly, applying it to election laws even if such laws did not directly interfere with citizens' attempts to register to vote or to cast a ballot. ${ }^{79}$ As a result of such decisions, ${ }^{80}$ the Court breathed new life into Section 5, reading its scope and its authority in broad terms. Today, Section 5 is one of the DOJ's most powerful and important tools for enforcing minority voting rights. ${ }^{81}$

Section 5 requires that certain jurisdictions ${ }^{82}$ submit for approval by the federal government any proposed changes to voting qualifications and procedures. ${ }^{83}$ Section 5 applies to only those jurisdictions that, at the implementation date designated in the statute ${ }^{84}$ maintained any test or device for restricting access to voting ${ }^{85}$ and had less than $50 \%$ of voting-age

76. See, e.g., Reno v. Bossier Parish Sch. Bd., 520 U.S. 471, 501 (1997) ("Section 5 . . imposed novel, extraordinary remedies in certain areas where discrimination had been most flagrant.").

77. 393 U.S. 544 (1969).

78. Id. at $550-53$.

79. KousSER, supra note 39 , at 55-56.

80. See, e.g., Hadnott v. Amos, 394 U.S. 358, 366 (1969) (holding that an Alabama statute requiring independent candidates to file their intent to run at the same time as eandidates associated with parties ran afoul of Section 5); South Carolina v. Katzenbach, 383 U.S. 301 (1966) (rejecting South Carolina's challenge to the obligations imposed by Section 5 on covered jurisdictions).

81. J. Gerald Hebert, Redistricting in the Post-2000 Era, 8 Geo. Mason L. Rev, 43I, 444 (2000) (noting that Section 5 was "enormously important" for challenges to the 1990 round of redistricting).

82. By "jurisdictions," the Act includes both states and political subdivisions of states, such as counties, cities, judicial districts, and water districts.

83. 42 U.S.C. § 1973d (2000).

84. The original Act, passed in 1965, used November 1964 as the date by which to measure the existence of a test or device and less than $50 \%$ of the voting age population registered. The reauthorization of the Act's provisions in 1970 and 1975 also included some changes to the formula by which covered jurisdictions are selected. In 1970, November 1968 was selected for an additional eoverage formula. In 1975, November 1972 was used for an expansion of the formula. Section 5 Requirements, supra note 64.

85. Section 4(c) of the Act defines "test or deviee" as

any requirement that a person as a prerequisite for voting or registration for voting (1) demonstrate the ability to read, write, understand, or interpret any matter, (2) demonstrate any educational achievement or his knowledge of any particular subject, (3) possess good moral character, or (4) prove his qualifications by the voucher of registered voters or members of any other class. 42 U.S.C. \$ 1973(c).

Indeed, comparing the number of Section 5 objections interposed in the first years after its adoption with the number of objeetions interposed in recent years underscores just how potent a weapon the DOJ 
persons registered. Currently, sixteen states are covered in whole or in part. ${ }^{86}$ If a covered jurisdiction wishes to alter voting qualifications or procedures, it must petition the U.S. District Court for the District of Columbia for a declaratory judgment that the change "does not have the purpose and will not have the effect of denying or abridging the right to vote on account of race or color." ${ }^{87}$ Alternatively, a covered jurisdiction can submit the proposed changes to the Attorney General, ${ }^{88}$ and, if the Attorney General does not object to the changes within sixty days, the changes go into effect. $^{89}$ If a covered jurisdiction neither petitions the district court nor submits the changes to the Attorney General, the changes cannot be enforced.

More than three decades after the Act's passage, the Attorney General is still actively entering objections to state and local practices that impermissibly restrict minorities' voting rights. For example, between January I, 1997, and February 5, 2003, fifty objections were entered. ${ }^{90}$

II

\section{From KatZenbaCH to BoERnE: The Court's Shifting View of Congress's Constitutional Enforcement Power}

The core constitutional issue raised by the Act concerns the extent to which the Fourteenth and Fifteenth Amendments authorize Congress to circumscribe state action in the area of voting rights. The scope of Congress's enforcement power has been an ongoing and contentious issue for both Congress and the Court. Since its passage, critics have raised two main objections to the Act's constitutionality. Initially, critics charged that it violated federalism by infringing on states' rights (the federalism objection); later, critics charged that it usurped the power of the judiciary to determine what is or is not constitutional (the separation-of-powers objection).

has come to consider Section 5. See infra Figure 2, at 807. See also note 195, and text acconpanying notes 222-24.

86. Currently, the states of Alabama, Alaska, Arizona, Georgia, Louisiana, Mississippi, South Carolina, Texas, and Virginia are covered in their cntirety. Four counties are covered in California, five in Florida, three in New York, and forty in North Carolina. Two townships in South Dakota, two in Michigan, and ten in New Hampshire are covered. U.S. Dep't of Justice, Civil Rights Div., Voting Section, Section 5 Covered Jurisdictions, at http://www.usdoj.gov/ crt/voting/sec_5/covered.htın (last revised Feb. 11, 2000). In addition, three political subdivisions have bailed out of Section 5 coverage. (A jurisdiction may bail out of coverage if it proves that, for a ccrtain amount of time, no voting changes have had the purpose or effect of discriminating against minority voters. See infra note 175.)

87. 42 U.S.C. $\$ 1973 \mathrm{c}(2000)$.

88. Ninety-nine pcrcent of the changes submittcd for preclearance go through the Attorney General; the other $1 \%$ go through the U.S. District Court for the District of Columbia. Section 5 Requirements, supra note 64

89. 42 U.S.C. $\$ 1973 \mathrm{c}(2000)$.

90. U.S. Dep't of Justice, Civil Rights Div., Voting Section, Section 5 Objection Determinations, at http://www.usdoj.gov/crt/voting/sec_5/obj_activ.htm (last revised Apr. 17, 2003) 
Perhaps no provision of the Act implicates these concerns more than Section 5. First, Section 5's preclearance requirement worked a dramatic change in the balance between state and federal power. Although Section 5 contained both geographic and temporal limits, ${ }^{91}$ it nonetheless represented a broad expression of congressional power to combat racial discrimination in the area of voting rights. ${ }^{92}$ Congress, frustrated by years of foot-dragging by cities and states and seeking to prevent any further efforts to delay the enfranchisement of Blacks, intended the enactment of Section 5 to shift the burden of proof from the federal government and aggrieved Blacks to states and cities by requiring these localities to demonstrate that proposed voting changes would not disenfranchise voters. ${ }^{93}$

Second, Section 5 empowers the federal government to require preclearance of a wide range of voting practices and requirements, which may or may not have been deemed unconstitutional by the Court. Hence, some critics would argue, Congress appears to be making substantive judgments about what types of state action violate the Fourteenth and Fifteenth Amendments. The question they would pose is whether Congress's willingness to venture further than the Court in protecting civil rights constitutes an impermissible intrusion into the judicial sphere and thereby violates the separation-of-powers doctrine.

While acknowledging that the Act, and Section 5 in particular, pit federal enforcement authority against states' rights, ${ }^{94}$ the Court has consistently rejected the federalism objection. ${ }^{95}$ However, the Rehnquist Court

91. Section 5's geographical seope is limited by a coverage formula that targets only those jurisdictions with the worst history of racial discrimination in voting. See supra notes 82-86 (deseribing the coverage formula). Section 5's sunset provision imposes temporal limits: By requiring periodic eongressional review and reauthorization, these limits enable future Congresses to decide whether the situation has been ameliorated enough that we no longer need Section 5. Justice Kennedy refers to both of these types of limitations in City of Boerne v. Flores. His majority opinion points to these constraints as helping to assure that the Act is congruent and proportional. Specifically, he notes that the geographic and temporal scope of the Act will not sweep too broadly, but rather will roughly track the existence of constitutional violations. City of Boerne v. Flores, 521 U.S. 507, 532-33 (1997).

92. Federal Voting Rights Laws, supra note 32.

93. South Carolina v. Katzenbach, 383 U.S. 301, 327-28 (1966).

94. From the earliest cases, e.g., South Carolina v. Katzenbach, 383 U.S. 301,325 (1966), to the most recent, e.g., City of Boerne, 521 U.S. at 520, the Court's justices have always acknowledged that the Act and Section 5 in particular has pitted states' rights against the federal enforcement of civil rights.

95. See, e.g., City of Rome v. United States, 446 U.S. 156, 179-80 (1980) (explaining that a long history of racial discrimination justifies intrusion into the affairs of states); Katzenbach, 383 U.S. at 324 (holding that the Act is a constitutional exercise of Congress's Fifteenth Amendment power as against the states). Most recently, in Lopez v. Monterey County, 525 U.S. 266 (1999), the Court stated:

We have recognized that the Act, which authorizes federal intrusion into sensitive areas of state and local policymaking, imposes substantial "federalism costs." The Act was passed pursuant to Congress' authority under the Fifteenth Amendment, however, and we have likewise acknowledged that the Reconstruction Amendments [the Thirteenth, Fourteenth, and Fifteenth Amendments] by their nature contemplate some intrusion into areas traditionally reserved to the States.

Id. at 282 (citations omitted). 
has been increasingly responsive to the separation-of-powers objection in reviewing, and striking down, legislation authorized under the Equal Protection Clause of the Fourteenth Amendment. ${ }^{96}$ While the Act has not yet been directly targeted, these recent decisions suggest that the Act is newly vulnerable to attacks on its constitutionality. To assess the potential threats to the constitutional basis of the Act, and to Section 5 in particular, it is important to analyze the development of the jurisprudence regarding the scope of Congress's enforcement power under the Fourteenth and Fifteenth Amendments.

The Fourteenth Amendment prohibits state violation of the equal protection of all persons, ${ }^{97}$ and the Fifteenth Amendment prohibits state denial or abridgment of the right to vote on the basis of race or color. ${ }^{98}$ The enforcement provisions of each amendment are similar. The Fourteenth Amendment states: "The Congress shall have power to enforce, by appropriate legislation, the provisions of this article." 99 The Fifteenth Amendment states: "The Congress shall have power to enforce this article by appropriate legislation." ${ }^{100}$ Both amendments were passed during the Reconstruction period following the Civil War as part of the Radical Republican efforts to givc the federal government power to enforce and protect the grant of rights to newly freed slaves. Given the parallel language and history, the Court has "always treated the nature of the enforcement powers conferred by the Fourteenth and Fifteenth Amendments as coextensive."101

The following sections describe how the Court's view of the scope of congressional enforcement power has changed over time. The opinions can be roughly divided into two eras. Part II.A describes the first era, which began under the Warren Court (1953-1969) and continued to a lesser extent under the Burger Court (1969-1986). The Warren and Burger Courts interpreted the enforcement power granted to Congress under the two amendments broadly. ${ }^{102}$ These opinions generally accorded Congress great

96. See, e.g., Kimel v. Fla. Bd. of Regents, 528 U.S. 62, 82-83 (2000) (holding that the Age Discrimination in Employment Act was not "appropriate" legislation under the Fourteenth Amendment); United States v. Morrison, 529 U.S. 598 (2000) (striking down provisions of the Violence Against Women Act); and City of Boerne, 521 U.S. 507 (striking down the Religious Freedom Restoration Act).

97. U.S. CONST. amend. XIV, §I.

98. Id. amend. $\mathrm{XV}, \S 1$.

99. Id. amend. $\mathrm{XIV}, \S 5$.

100. Id. amend. XV, §2.

101. Lopez v. Monterey County, 525 U.S. 266, 294 n.6 (1999).

102. It was during the Warren Court that the rough contours of the Act as a whole and Section 5 specifically were defined. It is conceivable that, had the current Court been sitting at the time of the Act's adoption-and therefore not limited by stare decisis-the entire enterprise might have been stillborn: But the Warren Court understood congressional power to include the ability to impose certain burdens on the states in the pursuit of combating racial discrimination. See, e.g., South Carolina v. Katzenbach, 383 U.S. 301,324 (1966). 
deference with respect to Section 5 and interpreted the Act's provisions as being expansive in scope. Part II.B describes the second era, which began in 1997 with the Rehnquist Court's decision in City of Boerne $v$. Flores $^{103}$ and has been marked by conservative judicial activism. During this era, the Court has struck down a series of antidiscrimination laws as not supported by congressional enforcement power under the Fourteenth Amendment. ${ }^{104}$ In this context, it is understandable that civil rights scholars are concerned about the continued viability of Section $5 .^{105}$

\section{A. Congressional Authority Affirmed: South Carolina v. Katzenbach and Katzenbach v. Morgan}

Almost immediately after the Act's passage, South Carolina led a number of states in a suit to have the Act declared unconstitutional. In South Carolina v. Katzenbach, the states alleged that the Act went beyond the scope of congressional enforcement power under the Fifteenth Amendment and violated federalism. ${ }^{106}$ Katzenbach offered the Court its first opportunity to address the scope of Congress's authority to enforce the provisions of the Fifteenth Amendment. In an eight-to-one decision, the Court strongly affirmed Congress's authority to take sweeping action to deal with racial discrimination in voting. ${ }^{107}$

Writing for the majority, Chief Justice Warren grounded this conclusion in an understanding that such discrimination was both pervasive and systemic. ${ }^{108}$ The Court seemed particularly persuaded by the thoroughness with which Congrcss had considered the problem: the congressional process included extensive hearings and debate. ${ }^{109}$ The Court also took note of

103. 521 U.S. 507 (1997). For the purposes of this Comment 1 date the start of this period with the handing down of Boerne in 1997. The Court's decision in United States v. Lopez, 514 U.S. 549 (1995) (striking down the Gun-Free Schools Zones Act as not supported by Congress's Commerce Clause power) did provide some warning signs because most of the antidiscrimination laws passed since the 1960s have been upheld pursuant to Commerce Clause power. However, discussion of recent Commerce Clause jurisprudence and its implications for civil rights legislation is beyond the scope of this Comment.

104. See, e.g., Alexander v. Sandoval, 532 U.S. 275 (2001) (limiting the remedy for a violation of Title VI disparate impact regulations); Bd. of Trs. v. Garrett, 531 U.S. 356 (2001) (limiting remedies under the Americans with Disabilities Act); United States v. Morrison, 529 U.S. 598 (2000) (striking down a portion of the Violenee Against Women Act); and City of Boerne, $52 \mathrm{I}$ U.S. 507 (striking down the Religious Freedom Restoration Act). These cases represent the first time since the era of Reconstruction that the Court has held that Congress lacked the authority to enact laws prohibiting discrimination. Post \& Siegel, supra note 30, at 522. It is important to note, again, that jurisprudence interpreting the Fourteenth Amendment also applies to the Fifteenth Amendment. See supra note 21 and accompanying text.

105. See, e.g., Laycock, supra note 25 (arguing that the Court's rationale in Boerne undermines a variety of civil rights laws, including voting rights laws).

106. 383 U.S. 301,323 (1966).

107. Id. at 327 .

108. Id. at 308-09.

109. Id. 
the DOJ's efforts to enforce the voting rights of Blacks through case-bycase litigation and was influenced by Congress's determination that this strategy was too slow and yielded too few victories. ${ }^{110}$ In the face of widespread discrimination and almost total resistance in the South to any efforts to better the situation, the Court found that Congress should be allowed wide latitude to effect change through broad legislation. ${ }^{11}$

Raising an argument that clearly resonates with today's Court, ${ }^{112}$ South Carolina asserted that Congress had no authority under the enforcement provision of the Fifteenth Amendment to enact provisions that reached beyond constitutional violations previously identified by the Court. ${ }^{113}$ South Carolina warned that allowing Congress to exercise sueh authority would abdicate judicial power to the legislative branch and blur the distinctions between the branches of government. ${ }^{1 / 4}$ The Warren Court rejected this argument, explaining that:

On the contrary, [the enforcement provision] of the Fifteenth Amendment expressly declares that "Congress shall have power to enforce this article by appropriate legislation." By adding this authorization, the Framers indicated that Congress was to be chiefly responsible for implementing the rights created in $\S 1 . .$. Accordingly, in addition to the courts, Congress has full remedial powers to effectuate the constitutional prohibition against racial discrimination in voting. ${ }^{115}$

The Court thus indicated that Congress plays a coordinate role in protecting the rights created by the Fifteenth Amendment. ${ }^{116}$

Additionally, the Court responded to states' rights advocates' concerns that the Act gave the federal government carte blanche to intrude in states' affairs by invalidating their statutes and procedures. ${ }^{117}$ Chief Justice Warren pointed to the Act's narrowly drawn geographical limits: The jurisdictions covered were those "small number of States and political subdivisions which in most instances were familiar to Congress by

110. Id. at $309,313,327-28$.

III. Id. at 337 .

112. See generally Bd. of Trs. v. Garrett, 531 U.S. 356 (2001); United States v. Morrison, 529 U.S. 598 (2000); City of Boerne v. Flores, 52 I U.S. 507 (1997).

113. Katzenbach, 383 U.S. at 325 (1966). Here South Carolina is alluding to Congress's prohibition on the use of literacy tests even though the Court had previously found that the use of literacy tests was not facially unconstitutional. See Lassiter v. Northampton County Bd. of Elections, 360 U.S. 45 (1959).

114. Katzenbach, 383 U.S. at 325.

115. Id. at $325-26$.

116. One example of the Court's acceptance of Congress's coordinate role is the Court's willingness to defer to congressional prohibition of literacy tests, which the Court had eoncluded did not rise to a violation of the Fifteenth Amendment in Lassiter v. Northampton County Bd. of Elections, 360 U.S. 45 (1959). See supra note 66.

117. Katzenbach, 383 U.S. at 325. 
name. ... Congress chose to limit its attention to the geographic areas where immediate action seemed necessary." $" 18$

These reassurances did not persuade Justice Black, who dissented specifically as to the constitutionality of Section 5 of the Act. ${ }^{119}$ Justice Black, a Southerner, was concerned that the federal government was overreaching as it had during the Reconstruction period after the Civil War. Blaek worried that Section 5 dramatically altered the balance of power between the federal government and the states: "[Section 5] so distorts our constitutional structure of government as to render any distinction drawn in the Constitution between state and federal power almost meaningless." 120 Indeed, his dissent invokes many of the images that infuriated Southern states:

Certainly if [the constitutional notion of federalism means anything, it means] at least that the States have power to pass laws and amend their constitutions without first sending their officials hundreds of miles away to beg federal authorities to approve them. ... I cannot help but believe that the inevitable effect of any such law which forces any one of the States to entreat federal authorities in far-away places for approval of local laws before they can become effective is to create the impression that the State or States treated in this way are little more than conquered provinces. ${ }^{121}$

Despite Black's argument, after South Carolina v. Katzenbach, the idea that Congress has the power to enforce the Act in general, and Section 5 in particular, seemed settled and was reaffirmed in subsequent cases. ${ }^{122}$

One of the most important of these cases, Katzenbach v. Morgan, involved a challenge to a provision of the Act prohibiting the denial of voting rights for inability to speak or write English. ${ }^{123}$ Section 4(e) of the Act provides that a person who has successfully completed the sixth grade in a public or accredited private school of Puerto Rico in which the language of instruction was not English cannot be denied the right to vote because of an inability to read or write English. ${ }^{124}$ The provision conflicted with the state of New York's constitution and election laws, which imposed English literacy requirements on the right to vote. ${ }^{125} \mathrm{~A}$ group of registered New York

118. Id. at 328 .

119. Id. at 355 (Black, J., dissenting).

120. Id. at 358 .

121. Id. at 359-60.

122. See, e.g., City of Rome v. United States, 446 U.S. 156, 178-183 (1980) (rejecting the argument that Section 5 impermissibly intrudes on federalism concerns); Beer v. United States, 425 U.S. 130, 140 (1976) (explaining that Congress permissibly enacted Section 5 to "rid the country of racial discrimination in voting").

123. 384 U.S. 641, 643 (1966).

124. 42 U.S.C. $\$ 1973 b(e)(2000)$.

125. Morgan, 384 U.S. at 643-44. 
voters sued, claiming that the provision exceeded congressional authority and unconstitutionally usurped the Tenth Amendment power reserved to the states. ${ }^{126}$

In passing Section 4(e), Congress sought to combat discrimination based on the inability to speak or write English, a circumstance not covered by the Fifteenth Amendment. ${ }^{127}$ Accordingly, Congress turned to the Fourteenth Amendment to authorize the legislation. Writing for the majority, Justice Brennan rejected the challenge to Section 4(e) and held that Congress was permissibly acting within the enforcement power granted in the Fourteenth Amendment, a power that was best understood as broadly conceived, much like the power granted in the Necessary and Proper Clause. ${ }^{128}$ Since the Court has always treated the nature of the enforcement powers conferred by the Fourteenth and Fifteenth Amendments as coextensive, ${ }^{129}$ Morgan affirmed, and arguably broadened, the Court's decision in South Carolina v. Katzenbach.

Responding to the claim that a broad interpretation of Congress's Fourteenth Amendment enforcement power impermissibly trod on judicial authority to determine violations of the Constitution, Justice Brennan wrote:

A construction of [the enforcement provision] that would require a judicial determination that the enforeement of the state law precluded by Congress violated the Amendment, as a condition of sustaining the congressional enactment, would depreciate both congressional resourcefulness and congressional responsibility for implementing the Amendment. It would confine the legislative power in this context to the insignificant role of abrogating only those state laws that the judicial branch was prepared to adjudge unconstitutional, or of mercly informing the judgment of the judiciary by particularizing the "majestic generalities" of $\S 1$ of the Amendment. ${ }^{130}$

126. U.S. Consr. amend. X ("The powers not delegated to the United States by the Constitution, nor prohibited by it to the States, are reserved to the States respectively, or to the people."); Morgan, 384 U.S. at $644-45$.

127. Morgan, 384 U.S. at 649-50. Section 1 of the Fourteenth Amendment applies to any person, protecting the privileges and immunities of eitizens, prohibiting the denial of life, liberty, or property and guaranteeing the equal protection of law for every person. U.S. CoNst. amend. XIV, $\S 1$.

128. Morgan, 384 U.S. at 650. The Necessary and Proper Clause states that "To make all Laws which shall be necessary and proper for carrying into Exceution the foregoing Powers, and all other Powers vested by this Constitution in the Government of the United States, or in any Department or Officer thereof." U.S. Const. art. $1, \S 8$, cl. 18. The classic description of the clause's limits was established by Chief Justice Marshall. "Let the end be legitimate, let it be within the scope of the constitution, and all mcans which are appropriate, which are plainly adapted to that end, which are not prohibited, but consist with the letter and spirit of the constitution, are constitutional." McCulloch v. Maryland, 17 U.S. 316,421 (1819).

129. See supra note 21 and accompanying text.

130. Morgan, 384 U.S. at 648-49. 
According to Justice Brennan, Congress's role is not limited to enforcing those rights that the Court was prepared to grant but also includes a substantive role in determining the scope of those rights. ${ }^{131}$ This notion is limited only by his footnote ten, which stated that Congress is limited to legislation that does not dilute the equal protection of persons ${ }^{132}$-a "one-way ratchet" theory of equal protection power. ${ }^{133}$

The Court found that Congress was reasonable to be concerned that New York's constitution and election laws would disenfranchise some Puerto Rican voters and shut them out of the political process because of their inability to read or write English. ${ }^{134}$ Pursuant to that finding, the Court held that Congress could enact legislation via its Fourteenth Amendment enforcement power as necessary to prevent the violation of rights. ${ }^{135}$ The Court found it irrelevant that a congressional finding of racial discrimination in the area of voting might not rise to the level of a constitutional violation as defined by the Court. ${ }^{136}$ If the Court were to require a constitutional violation in order to trigger congressional power, such a threshold prerequisite would dramatically limit what Congress could do to combat racial discrimination. ${ }^{137}$

As in South Carolina v. Katzenbach, the majority opinion was met with a dissent warning about congressional overreaching. ${ }^{138}$ However, unlike Justice Black's dissent which focused on the impact on federalism, Justice Harlan's dissent in Morgan focused on Congress's authority to

131. Id. at 650-51.

132. Id. at $651 \mathrm{n} .10$.

133. Like a ratchet, Congress would only be able to amplify or enforce-not "restrict, abrogate, or dilute"- the guarantees of the Fourteenth Amendment. Id. Scholars have attaeked the "ratchet" theory because it does not grapple with the notion that the enforcement of some Fourteenth Amendment guarantees might trigger the dilution of someone else's rights. See, e.g., Lawrence G. Sager, Fair Measure: The Legal Status of Underenforced Constitutional Norms, 91 HaRv. L. Rev. 1212, 1230 (1978) (raising the objection that promoting the civil rights of some might constrain the rights of others). But see Matt Pawa, Comment, When the Supreme Court Restricts Constitutional Rights, Can Congress Save Us? An Examination of Section 5 of the Fourteenth Amendment, 141 U. PA. L. Rev. $1029,1062-69$ (1993) (articulating three possible defenses for the ratchet theory). Thus, the state might simultaneously be amplifying and restricting rights through the adoption of a provision. For example, if a future Congress were to ban abortions, onc could argue that although the state was acting to amplify the rights of unborn persons under the Fourteenth Amendment, it was simultaneously restricting the rights of women. However, in light of the Court's decision in City of Boerne v. Flores, 521 U.S. 507 (1997), this discussion is likely moot as the Court seems clear that Congress has no role in determining the scope of the rights afforded under the Fourteenth Amendment. Id. at 519 ("The design of the [Fourteenth] Amendment and the text of [its enforcement provision] are inconsistent with the suggestion that Congress has the power to decree the substance of the Fourteenth Amendment's restrictions on the States.")
134. Id. at 653
135. Id.
136. Id.
137. Id.
138. Id. at 659 (Harlan, J., dissenting). 
determine the scope of Section 1 of the Fourteenth Amendment and the effect that authority had on judicial authority to do the same. ${ }^{139}$

Justice Harlan warned that unless the Court circumscribed its grant of congressional authority, it risked allowing Congress to qualify the Court's decisions under the Fourteenth and Fifteenth Amendments. ${ }^{140} \mathrm{He}$ argued that in order to trigger Congress's enforcement power under the Fourteenth Amendment, the Court should first require the finding of a constitutional violation. ${ }^{141} \mathrm{He}$ reasoned that the finding of a constitutional violation should be the sole province of the Court, not Congress.

The question here is not whether the statute is appropriate remedial legislation to cure an established violation of a constitutional command, but whether there has in fact been an infringement of that constitutional command, that is, whether a particular state practice or, as here, a statute is so arbitrary or irrational as to offend the command of the Equal Protection Clause of the Fourteenth Amendment. That question is one for the judicial branch ultimately to determine. ${ }^{142}$

Despite Justice Harlan's misgivings, the Morgan Court upheld Congress's power to enact the provisions of the Act, and for several decades thereafter, it was settled that Congress had the authority to broadly enforce the Fourteenth and Fifteenth Amendments.

\section{B. Congressional Authority Reconsidered: Boerne and its Progeny}

Congress's authority to broadly enforce both the Fourteenth and Fifteenth Amendments beyond the scope of judicially determined constitutional violations has recently come under renewed scrutiny. The ascension of William Rehnquist to the position of Chief Justice and the appointments of Justices Scalia and Thomas shifted the balance on the Court towards a more restrictive view of Congress's constitutional enforcement power. Beginning with City of Boerne v. Flores in 1997, the Rehnquist Court has decided a line of cases which have dramatically narrowed the scope of Congress's Fourteenth Amendment enforcement power. ${ }^{143}$ Although in Boerne and in several subsequent cases, the Court explicitly identified the

139. Id. at 666 .

140. Id. at 668 . Justice Harlan worried that if Congress were allowed to independently determine the substantive scope of rights through its Fourteenth Amendment enforcement power, future congresses might choose to limit the judicial grant of rights through rhetorical legerdemain. For example, Congress could prohibit the busing of students, arguing that it was protecting the Fourtecnth Amendment rights of students of color to attend a school close to their homes.

141. Id. at 666-67.

142. Id. at 667 .

143. Judicial holdings about the scope of enforcement power under the Fourteenth Amendment affect the scope of congressional power to act under the Fifteenth Amendment as well. See supra note 21 and accompanying text. 
Act as an example of the permissible exercise of congressional power, ${ }^{144}$ it may become increasingly difficult to reconcile the Court's jurisprudence with Section 5, particularly if the Act is reauthorized. ${ }^{145}$

In Boerne, the Court struck down the Religious Freedom Restoration Act (the "RFRA") on the ground that it exceeded Congress's enforcement power under the Fourteenth Amendment. ${ }^{146}$ Congress had passed RFRA in response to the Court's decision in Employment Division v. Smith. ${ }^{147}$ In Smith, the Court refused to apply a "compelling state interest" test to a neutral, generally applicable Oregon law that resulted in members of a Native American church losing their unemployment benefits due to their use of peyote for religious purposes. ${ }^{148}$ Congress intended RFRA to overturn the Smith decision and to require courts to apply a compelling-interest test in all cases where government action substantially burdens the free exercise of religion. ${ }^{149}$

The Boerne Court acknowledged that the enforcement provision of the Fourteenth Amendment is "a positive grant of legislative power' to Congress" 150 and should be understood in broad terms. Accordingly, "[l] egislation which deters or remedies constitutional violations can fall within the sweep of Congress' enforcement power even if in the process it prohibits conduct which is not itself unconstitutional and intrudes into "legislative sphercs of autonomy previously reserved to the States."'|51

However, even though the Court found that the congressional enforcement power is broad, the Court refused to allow Congress to proceed as if its power were limitless. ${ }^{152}$ The Court distinguished between Congress's "remedial" power to enforce the Fourteenth Amendment and "the power to decree the substance of the Fourteenth Amendment's restriction on the States.... Congress does not enforce a constitutional right by changing what the right is. It has been given the power 'to enforce,' not the power to determine what constitutes a constitutional

144. City of Boerne v. Flores, 521 U.S. 507, 518 (1997); see also Bd. of Trs. v. Garrett, 531 U.S. 356, 373 (2001); United States v. Morrison, 529 U.S. 598, 626-27 (2001).

145. See Laycock, supra note 25 (arguing that previously uncontroversial statutes are subject to serious constitutional attack in light of the Court's reasoning). It should also be noted that Laycock made this argument before the Court handed down its decisions in United States v. Morrison, 529 U.S. 598 (2000), Kimel v. Fla. Bd. of Regents, 528 U.S. 62 (2000), and Bd. of Trs. v. Garrett, 531 U.S. 356 (2001), all of which extend the Boerne argument and firmly entrench it. See also Post \& Siegel, supra note 30, at 441-44 (arguing that the ability to pass federal antidiscrimination legislation is at risk because of the Court's recent Fourteenth Amendment cases).

146. City of Boerne, 521 U.S. at 536.

147. $l d$. at 512 .

148. Emp. Div. v. Smith, 494 U.S. 872, 886-89 (1990).

149. City of Boerne, 521 U.S. at 515.

150. ld. at 517 (quoting Katzenbach v. Morgan, 384 U.S. 641, 651 (1966)).

151. Id. at 518 (quoting Fitzpatrick v. Bitzer, 427 U.S. 445, 455 (1976)).

152. ld. at 518-19. 
violation." 153 Although the Court conceded that the distinction between this remedial and substantive power "is not easy to discern," 154 it proposed a test for determining the line between the two. "There must be a congruence and proportionality between the injury to be prevented or remedied and the means adopted to that end. Lacking such a connection, legislation may become substantive in operation and effect." 155 The Court's concern was that its own power to interpret the Constitution might be eroded if Congress could change the scope of the Fourteenth Amendment legislatively rather than going through the constitutional amendment process. ${ }^{156}$ The Court thus sought to protect its role as supreme expositor of the Constitution.

After the Boerne decision, the Court decided a series of cases in which federal civil rights laws were struck down as not meeting Boerne's congruence-and-proportionality test. In the last four years, the Court has struck down or limited provisions of multiple civil rights statutes, including the Violence Against Women Act, ${ }^{157}$ the Americans with Disabilities Act, ${ }^{158}$ the Age Discrimination in Employment Act, ${ }^{159}$ and Title VI of the Civil Rights Act of $1964 .{ }^{160}$ The Court held that these provisions violated Boerne's limits on congressional enforcement authority. No one would have predicted such a sweeping repudiation of congressional authority to enact civil rights legislation. Indeed, the invalidation of these statutes represented the first time in the twentieth century that civil rights statutes were struck down because the Court determined them to be beyond Congress's power to enact legislation. ${ }^{161}$

Next, this Comment assesses the potential challenges to the constitutionality of the Act given the Court's recent jurisprudence limiting the scope of Congress's enforcement authority under the Fourteenth and Fiftcenth Amendments.

III

Assessing Potential Challenges to the Constitutionality of Section 5: Now and in the Future

Section 5 may be in a more precarious position than at any time since its enactment. The Rehnquist Court's recent decisions contain three

153. Id. at 519 .

154. Id.

155. Id. at 520. For a discussion of how this test is applied, see infra Part III.A.

156. City of Boerne, 521 U.S. at 529; see also supra notes 139-42 for a discussion of Justice Harlan's dissenting opinion in Morgan. Justice Harlan's concerns were very similar to the current Court's anxiety about Congress undermining judicial authority to "say what the law is."

157. See United States v. Morrison, 529 U.S. 598 (2000).

158. See Bd. of Trs. v. Garrett, 531 U.S. $356(2001)$.

159. See Kimel v. Fla. Bd. of Regents, 528 U.S. 62 (2000).

160. See Alexander v. Sandoval, 532 U.S. 275 (2001).

161. See Post \& Siegel; supra note 30 , at 443. 
warning signs that indicate that a challenge to Section 5 might be successful now or after reauthorization: (1) the accumulation of precedent circumscribing congressional authority to enact antidiscrimination laws and laws that burden states, ${ }^{162}$ (2) the increased antipathy toward race-based claims whether in the area of employment, political access, or government services; ${ }^{163}$ and (3) the handing down of decisions severely limiting the scope of what is considered a violation of the Act and what remedies are available under Section 2 and Section 5 of the Act. ${ }^{164}$

Therefore, even though a broad interpretation of Section 5's scope recently commandcd eight votes in Lopez $v$. Monterey County, ${ }^{165}$ a challenge to preclearance might well succeed-especially after reauthorization. The Court's decisions declaring the Act to be an example of congruence and proportionality have emphasized the finite term of the Act's duration together with the vast record of abuse in the almost thirty years between the Act's initial adoption and its rcauthorization in 1982. ${ }^{166}$ lf Congress were to reauthorize the Act and Section 5 in 2007, forty-two years would have passed since its original enactment in 1965. Suddenly, the Act might not seem so limited to the Court, nor might it seem such a congruent or proportional response to the problem of voting rights abuse. For while the Court has often pointed to Section 5 as a paradigm of congruent and proportional legislation, ${ }^{167}$ it has just as often, and even more strenuously, made clear that preclearance is extraordinary in the burden that it places on the states. ${ }^{168}$

Additionally, while precedent favoring Congress's ability to enact Section 5 seems to be solid, the same could have been (and was) said about a whole host of other congressional powcrs-until eight years ago. Before 1995, Congress's Commerce Clause power and its authority to enact

162. For citation to these cases, see supra note 20 .

163. For an example in the employment context, see Adarand Constructors v. Peña, 515 U.S. 200 (1995) (applying, in a five-to-four decision, strict scrutiny analysis to affirmative action policies in the area of government contracting). For an example in the political access context, see Reno $v$. Bossier Parish School Board, 528 U.S. 320 (2000) (holding, in a five-to-four decision, that Section 5 does not apply to discriminatory, but nonretrogressive voting changes). For an example in the area of governmental services, see Alexander v. Sandoval, 532 U.S. 275 (2001) (rejecting, in a five-to-four decision, the existence of a private right of action against the state to enforce language discrimination protections provided under Title Vl of the Civil Rights Act of 1964).

164. See, e.g., Shaw v. Hunt, 517 U.S. 899 (1996) (holding, in part, that redistricting in order to comply with Section 2 of the Act can still fail strict scrutiny because it is not narrowly tailored), overruled by Hunt v. Cromartie, 526 U.S. 541 (1999); Reno, 528 U.S. 320 (holding that Section 5 does not apply to discriminatory but nonretrogressive voting changes).

165. 525 U.S. 266 (1999). In Lopez, the Court rejected a challenge to the application of Section 5 by Monterey County (a covered jurisdiction), which was attempting to implement a voting change adopted by California (not a covered jurisdiction) without preclearing it with the DOJ. See infra notes 203-07 and accompanying text.

166. City of Boerne v. Flores, 521 U.S. 507, 532-33 (1997)

167. Id. at 530 .

168. Lopez, 525 U.S. at 282. 
antidiscrimination legislation seemed unlimited, and the Court did not seem poised to radically depart from precedent. But in United States v. Lopez the Court abruptly limited what Congress could do under the Commerce Clause. ${ }^{169}$ Two years later in Boerne, the Court struck down for the first time since Reconstruction a congressional antidiscrimination law as unsupported by Congress's Fourteenth Amendment power. ${ }^{170}$ In the intervening years, the Court, in a wholesale judicial revolution, has struck down an array of congressional enactments that no one would have considered vulnerable. It is in this environment and for these reasons that the threats to Section 5's constitutionality must be assessed.

This Part evaluates the likelihood and strength of the potential challenges to Section 5. The issue of Section 5's constitutionality could be raised in at least three different contexts over the next several years. First, a constitutional challenge to the Act in general, and Section 5 in particular, could come before 2007, when Congress must decide whether or not to reauthorize the Act's provisions. Certainly, as the case law limiting the scope of congressional enforcement power continues to mount, a challenge to Section 5 of the Act becomes more viable for those who feel that the Act and the preclearance requirement of Section 5 overstep the permissible boundaries of Congress's authority under the Fourteenth and Fifteenth Amendments. ${ }^{171}$ However, it appears unlikely that an immediate challenge will prevail. In Boerne and other recent cases, the Court has distinguished the Act from other equal protection provisions that have been struck down. ${ }^{172}$ The next Section, Part III.A, analyzes the distinguishing factors which the Court has identified, both because they illuminate the Court's reasoning and because they will be critical in rebutting future challenges.

Second, in light of the recent Court decisions limiting the scope of congressional enforcement authority, Congress will almost certainly consider Section 5's constitutionality when deliberating an extension of the Act's provisions. Congress will likely hold hearings in 2007, as it did during the 1982 reauthorization debate. In addition to assessing the need for and costs of reauthorization, these hearings are likely to focus on recent Court decisions about the scope of congressional enforcement power under the Fourteenth Amendment. Indeed, after the Court struck down the RFRA in Boerne, ${ }^{173}$ Congress made a conscious effort to take the Court's concerns

169. 514 U.S. 549 (1995) (striking down the Gun-Free Schools Zones Act).

170. See Post \& Siegel, supra note 30.

171. In Lopez v. Monterey County, 525 U.S. 266 (1999), for example, the state of California attempted to challenge the constitutionality of Seetion 5 after a federal judge ruled that Monterey County, a covered jurisdiction, could not implement statewide changes to the system of judicial elections without first obtaining preelearanee from the Attorney General. In an eight-to-one decision, California's challenge was rebuffed.

172. Bd. of Trs. v. Garrett, 531 U.S. 356, 373-74 (2001); United States v. Morrison, 529 U.S. 598, 626-27 (2000); City of Boerne v. Flores, 521 U.S. 507, 518 (1997).

173. 521 U.S. 507 (1997). 
into consideration when it held subsequent hearings on civil rights legislation. ${ }^{174}$ It is likely that both congressional advocates and opponents of extension will use Boerne and its progeny in debating whether to reauthorize the Act: Advocates could use the cases to design the extension to withstand a legal attack, and opponents could use the cases to strengthen the argument for allowing the Act's provisions to expire. Part III.B articulates why reauthorization of Section 5 in 2007 is both necessary and constitutionally defensible. Part III.B examines the various congressional objections to reauthorization and, after responding to them, will argue first that ongoing instances of voting rights abuses require the extension of Section 5 , and second, that Section 5 represents a powerful symbol of governmental vigilance to communities-of-color and that allowing Section 5 to expire would signal a disinterest on the part of Congress in maintaining a watchful eye over the voting rights of minority communities.

The third, and most serious, constitutional challenge is likely to come if Congress reauthorizes the Act and Section 5 in 2007. Affected jurisdictions and/or states' rights advocates will probably challenge the reauthorization in the courts. In 2007, the Act will have been in place for forty-two years. Since only a few jurisdictions have been able to "bail out" of the Act's coverage, ${ }^{175}$ most jurisdictions that were initially brought into coverage at the very beginning still remain under the auspices of the Act's provisions. These jurisdictions, along with conservative activist organizations like the Pacific Legal Foundation and the Center for Individual Rights, ${ }^{176}$ would likely challenge any reauthorization that occurred. The question remains whether the Court, which has appeared to endorse the Act's reach in the Boerne line of cases, would continue to do so if Congress extended Section 5's life. Part III.C argues that any future attack on a reauthorized Section 5 should end as many previous ones have-with the Court

174. See, e.g., Garrett, 531 U.S. at 377-78 (Breyer, J., dissenting). Breyer notes that Congress had "compiled a vast legislative record documenting 'massive, society-wide discrimination' against persons with disabilities." Id. at 377 . Congress's attempt to document the problem was an effort to comport with the requirements set out by Boerne.

175. Bailout suits initiated under Section 4 of the Act allow a jurisdiction to obtain a declaratory judgment from a federal court in the District of Columbia allowing it to opt out of coverage, but only after proving that no voting changes have had the purpose or effect of discriminating. 42 U.S.C. $\S 1973$ b(a) (2000); see infra text accompanying notes 228-32 for a description of the bailout process.

176. The Pacific Legal Foundation and the Center for Individual Rights are conservative legal organizations that have been engaged in an aggressive legal campaign to roll back the gains of the civil rights movement. They have brought suit and filed amicus bricfs in cases dealing with everything from voting rights to affirmative action in university admissions. For example, the Pacific Legal Foundation has filed amicus briefs attacking affirmative action in two cases to be considered by the Supreme Court in the 2003 term, Grutter v. Bollinger, No. $02-241$ (U.S. filed Dec. 2, 2002), and Gratz v. Bollinger, No. 02-516 (U.S. filed Dec. 2, 2002). The Center for Individual Rights was co-counsel representing Bossier Parrish before the Supreme Court in Reno v. Bossier Parish School Board, 528 U.S. 320 (2000) (holding that Section 5 does not apply to discriminatory but non-retrogressive voting changes), and successfully attacked the University of Texas's affirmative action policy in Hopwood v. State of Texas, 78 F.3d 932 (Sth Cir. 1996). 
upholding Section 5 as well as Congress's broad authority to attack the ongoing problem of voting rights abuses. Part III.C demonstrates a reauthorized Section 5 will still meet the stringent requirements of the Court's congruence-and-proportionality test. Additionally Part III.C argues that the scope and legitimacy of the Act has been a unique product of interbranch cooperation between Congress and the Court and that this interbranch "dialogue," together with the principles of stare decisis, militates against the success of a future challenge.

\section{A. Section 5 in Light of Boerne: An Analysis of Section 5 's Constitutionality Now}

This section analyzes the current constitutionality of Section 5 in light of Boerne and argues that, despite the limits the Court has recently imposed on Congress's enforcement power, Section 5 clearly passes constitutional muster. Not only has the Act been invoked as an example of congruent and proportional legislation in Boerne and other recent cases, ${ }^{177}$ but the Court, in Lopez v. Monterey County, also recently rejected a challenge to the validity of Section $5 .{ }^{178}$ A close analysis of Boerne and Lopez is essential to understanding why the Court has, at least thus far, distinguished the Act from other equal protection provisions that have been struck down. An understanding of the Court's reasoning is also essential to preparing responses to the challenges to Section 5's constitutionality that will almost certainly arise during the reauthorization debate in 2007 and thereafter.

The Boerne Court explained that to avoid violating the separation-ofpowers doctrine, which protects the judiciary's role to interpret the Constitution, " $[\mathrm{t}]$ here must be a congruence and proportionality between the injury to be prevented or remedied and the means adopted to that end." 179 In expounding this test, the Boerne Court cited the Act and its related jurisprudence as an exemplar of the permissible exercise of congressional enforcement power. ${ }^{180}$ In discussing South Carolina v. Katzenbach, the Court pointed to the emphasis that the Katzenbach Court placed on the historical context surrounding the adoption of the Act. ${ }^{181}$ In Katzenbach, the Court found several of the Act's provisions to be "remedies aimed at areas where voting discrimination has been most flagrant,' and necessary to 'banish the blight of racial discrimination in voting, which has infected

177. See, e.g., Garrett, 531 U.S. at 373-74; Morrison, 529 U.S. at 626-27; City of Boerne, 521 U.S. at 518 .

178. Lopez v. Monterey County, 525 U.S. 266 (1999) (holding that Monterey County, a covered jurisdiction, was required to preclear its instituting of statewide voting changes even though California is not itself covered under Section 5).

179. City of Boerne, 521 U.S. at 520.

180. Id. at 525 .

181. Id. 
the electoral process in parts of our country for nearly a century." 182 The remedies, such as preclearance under Section 5 of the Act, were "unprecedented [yet] deemed necessary given the ineffectiveness of the existing voting rights laws and the slow, costly character of case-by-case litigation." 183

The first prong of the Boerne test is "congruence." In comparing the Act's provisions to the RFRA, thc statutc at issue in Boerne, the Court wrote that to determine whether prophylactic rules, like preclearance or the RFRA, are appropriate remedial measures, there must be "a congruencc between the means used and the ends to be achieved. The appropriateness of remedial measures must be considered in light of the evil presented." 184 The Court used the Act as the gold standard against which it compared the RFRA. For example, the Court noted that unlike the Act's legislative record, the RFRA's lcgislative record lacked "examples of modern instances of generally applicable laws passed because of religious bigotry." 185

The second prong of the Boerne test is "proportionality." In addition to the insufficient legislative record, the Court found that the remedies proposed by the RFRA were "so out of proportion to a supposed remedial or preventative object that it cannot be understood as responsive to, or designed to prevent, unconstitutional behavior."186 The Court contrasted the RFRA's remedies to prospective remedies under the Act which "may be appropriate when there is reason to believe that many of the laws affectcd by the congressional enactment have a significant likelihood of being unconstitutional." ${ }^{87}$ Thus, the Court acknowledged that Section 5's narrow scope (limited to only those jurisdictions with a demonstrable history of racial discrimination) means that there is likely to be a high proportion of forbidden behavior that is unconstitutional. ${ }^{188}$

Further, the Court found that the RFRA had a much broader scope than the Act: First, the RFRA applied nationwide at every level of government. Second, the RFRA applied to all federal and state law. Third, the RFRA had no termination date or termination mechanism. ${ }^{189}$ These characteristics distinguished the RFRA from Section 5 of the Act, which only applies to covered jurisdictions and to state voting laws, allows covered jurisdictions to avoid preclcarance requirements under certain conditions,

182. Id. (internal citations omitted).

183. Id. at 526 (internal citations omitted)

184. Id. at 530 .

185. Id. at 530 .

186. Id. at 532 .

187. Id.

188. Confining the coverage formula to a small number of jurisdictions that had historically discriminated and had triggered coverage through one of thc various mechanisms of the Act increascd the likelihood of a tight fit between the Act's remedies and its target.

189. City of Boerne, 521 U.S. at 532. 
and lapses within a set amount of time. ${ }^{190}$ The Court emphasized that the Fourteenth Amendment's enforcement provision does not require "termination dates, geographic restrictions, or egregious predicates. Where, however, a congressional enactment pervasively prohibits constitutional state action in an effort to remedy or to prevent unconstitutional state action, limitations of this kind tend to ensure Congress's means are proportionate to ends legitimate [under the Fourteenth Amendment]."191 Thus, in Boerne, the Court described the Act and its provisions as a permissible means to combat racial discrimination in voting, even though, in so doing, Congress outlawed barriers to voting that the Court had held did not violate the Constitution. ${ }^{192}$

Examples of voting discrimination have continued into the modern record. Since the Court upheld Section 5 of the Act in City of Rome $v$. United States in $1980,{ }^{193}$ an additional 624 objections to voting changes have been entered by the DOJ ${ }^{194}$ (compared to the 396 objcctions entered from the Act's inception until City of Rome). ${ }^{195}$ The continuing nature of voting discrimination underscores the need for ongoing vigilance and the proportionality of Section 5 to the injury at issue.

The fact that legislation sometimes sweeps more broadly than the Court's interpretation of constitutional violations is not dispositive as to whether it is proportional. Indeed, in Boerne, the Court acknowledged that "[l] egislation which deters or remedies constitutional violations can fall within the sweep of Congress's enforcement power even if in the process it prohibits conduct which is not itself unconstitutional ...."196 Specific to this context, the Court upheld the Act's suspension of literacy tests even though the Court in Lassiter had held that such tests were not per se unconstitutional. ${ }^{197}$ To determine whether legislation sweeps too broadly, the Court asks whether the legislation prohibits substantially more state

190. Id. at 533 .

191. Id.

192. See supra note 66.

193. 446 U.S. 156 (1980) (holding that the City of Rome was not eligible to bail out of Section 5 coverage because it was part of a larger covered jurisdiction (Georgia) and that, as such, its changes had to be submitted for preclearance).

194. Objections are cntered whenever the DOJ wishes to refuse to preclear a submitted voting change because it believes that the change has a discriminatory purpose or effect. See infra text accompanying notes $222-25$.

195. U.S. Dep't of Justice, Civil Rights Div., Complete Listing of Objections Pursuant to Sections 3 (c) and 5 of the Voting Rights Act of 1965 (June 30, 2002) (on file with author) [hereinafter Objections].

196. City of Boerne, 521 U.S. at 518.

197. South Carolina v. Katzenbach, 383 U.S. 301, 308 (1966); Lassiter v. Northampton County Bd. of Elections, 360 U.S. 45 (1959) (holding literacy requirements for voter registration to be constitutional where reasonably related to promoting an informed electorate). 
decisions and practices than would likely be held unconstitutional under the applicable equal protection standard. ${ }^{198}$

In the case of the Act, and more specifically, Section 5, the answer is no. While Section 5 does prohibit some state action that the Court itself might not find violative of the Fourteenth and Fifteenth Amendments, two reasons underscore the existence of a tight fit between injury and remedy: First, there is no reason to believe that Section 5 prohibits a substantial (and thus unconstitutional) amount of constitutional behavior. Indeed, the Court has noted in various recent decisions ${ }^{199}$ that Congress sought to prevent behavior that would have the purpose or effect of undermining minorities' right to vote, behavior that has presented itself in modern examples throughout the last forty years, ${ }^{200}$ and behavior that the Court is largcly prepared to find unconstitutional itself. ${ }^{201}$ Second, as the Court itself noted in Boerne, the Act contains a number of self-imposed limitations that confine the sweep of its coverage, ensuring a close fit between the legislative

198. Kimel v. Fla. Bd. of Regents, 528 U.S. 62, 86 (2000) (holding that the Age Discrimination in Employment Act was not a valid exereise of Congress's Fourteenth Amendment enforcement power).

199. Bd. of Trs. v. Garrett, 531 U.S. 356, 373-74 (2001); United States v. Morrison, 529 U.S. 598, 626-27 (2000); City of Boerne, 521 U.S. at 518.

200. City of Boerne, 521 U.S. at 530 (describing modern examples of voting rights abuses). At the most recent congressional reauthorization hearings in 1982, extensive evidence was presented of voting rights abuses. See McDonald, supra note 53, at 68-80. McDonald breaks up this evidence into the following catcgories: at-large elections, majority vote requirements, abolition of appointed offices, other unclcared practices, and refusal to comply with DOJ objections. In the area of at-large elections, McDonald notes that counties in Georgia switched from district elections to at-large elections in an effort to thwart increased Blaek voter registration. Id. at 69 . At-large elections disadvantaged Black voters because Black communities were foreed to compete jurisdiction-wide with White majorities and therefore did not have the opportunity to elect candidates of their choice. $I d$. at 68 . However, when the switch to at-large eleetions was refused preclearance by the DOJ and counties were forced to use district elections, counties used decades-old district lines in another effort to subvert efforts to give Blacks a meaningful vote. $I d$. at 70 . In one example, McDonald notes that a county in Georgia had used the same district lines for thirty-two years, allowing the county to pack most of the Black voters into a district with over two thousand voters, while preserving a district numbering around two hundred, mostly White votcrs. Id. at 70 . In the area of majority vote requirements, McDonald discusses several instances where governments switched from plurality voting systems to majority voting systems. In the former, a candidate of color would have a better chance to win an election with a plurality of the vote if White eandidates were to split the vote. A majority voting system that would require a run-off between the two highest vote-getters operated to undermine the ehances of the election of a candidate of color. Id. at 73. MeDonald also discusses the abolition of appointed offices in favor of creating elective offices. Often such a move would coincide with increased influence by minorities over the appointment process: As Blaeks and Latinas/os began to be appointed to positions, eity councils and state legislatures began to require elections for the filling of the positions. Id. at 76. Finally, the most flagrant abuse McDonald documents is the outright refusal of covered jurisdictions to respect objections entered by the DOJ. He discusses cases where covered jurisdictions received objections regarding their submitted voting changes and then either refused to comply with, or evaded, those objections. Id. at 79 . Sinee the 1982 hearings, the DOJ has continued to enter objections to voting changes, indicating that the potential for abuse continues to this day. See infra Figure 2, at 807 , and note 242.

201. City of Boerne, 521 U.S. at 532. 
weapon Congress has chosen to wield and those jurisdictions most notorious for voting discrimination. ${ }^{202}$

In sum, the two prongs of the congruence-and-proportionality test support the notion that, if challenged now, the provisions of the Act in general and Scction 5 in particular should be, and probably would be, upheld. Indeed, in 1999, the Court heard a challenge to Section 5 that, while not directly invoking the congruence-and-proportionality test, might presage how the Court would decide. In Lopez v. Monterey County, California challenged the DOJ's interpretation that Monterey County, a covered jurisdiction, was required to preclear voting changes that it sought to implement after California, which is not a covered jurisdiction, passed a statewide law. ${ }^{203}$ California argued that because the state itself was not a covered jurisdiction and because the county was exercising no discretion in implementing the changcs, the application of Section 5 in that situation was unconstitutional. ${ }^{204}$

In an eight-to-one decision authored by Justice O'Connor, the Court rejected California's arguments and upheld Section 5. The Court noted the broad interpretation given the Act's provisions, saying that, "once a jurisdiction has been designated, the Act may guard against both discriminatory animus and the potentially harmful effect of neutral laws in that jurisdiction."205 In addition, "[r]ecognizing that Congress has the constitutional authority to designate covcred jurisdictions and to guard against changes that give rise to a discriminatory effect in those jurisdictions, we find no merit in the claim that Congress lacks Fifteenth Amendment authority to require federal approval before the implementation [of a law]."206

Thus, the Court clearly reaffirmed that Section 5's intrusion into statc sovereignty is permitted by the Fifteenth Amendment and characterized the holding as "add[ing] nothing of constitutional moment to the burdens that the Act imposes."207 This case, coming down four years ago in 1999 and decided by an eight-to-one margin, provides a clear and convincing signal that the Court believes that Section 5 as it stands now does not violate federalism or the separation-of-powers doctrine.

\section{B. Reauthorization of Section 5}

The second context in which the issue of Section 5's constitutionality will almost certainly arise is the congressional reauthorization process in 2007. As they have in the past, opponents of the Act are likely to raise the

202. Id. at 532-33.

203. 525 U.S. 266 (1999).

204. Id. at 282.

205. Id. at 283 .

206. Id.

207. Id. at 285 . 
federalism objection, arguing that Section 5 represents an impermissible intrusion into states' rights and places undue burdens on local jurisdictions. In drafting and debating an extension to the Act, Congress is also likely to consider the separation-of-powers objection in light of the Court's rccent jurisprudence limiting the scope of Congress's Fourtcenth Amendmcnt enforcement power.

This section first responds to these potential objections, arguing that Congress clearly has the authority to reauthorize the Act and Section 5. This section then presents reasons why Congress should exercise its authority.

\section{Responding to Constitutional Objections in the Reauthorization Context}

Federalism concerns will undoubtedly drive most of thc opposition to the Act's extension. Opponents of the Act have decried the DOJ's oversight of states' and localities' administration of elections and voting, arguing that such oversight is a grievous intrusion into state authority. ${ }^{208}$ The oft-invoked image is of a local official traveling, hat in hand, to Washington, D. C., to ask if it would be okay to move a polling place from point $\mathrm{A}$ to point $\mathrm{B}$ back in his or her home town. ${ }^{209}$ Whether in the case of federal elections, where the Constitution grants authority to states to manage parts of the election process, or perhaps more obviously, in the case of local elections (like school board elections), opponents argue that such federal interference with state and local officials is inappropriate and should be ruled unconstitutional.

However, Congress should reject the federalism objection on both legal and policy grounds. First, the Court has repeatedly held that the Act's intrusion into state and local affairs is permissible. ${ }^{210}$ Second, there are three policy reasons why it is appropriate to reauthorize Section 5. First, its scope is limited to only those jurisdictions with the longest and most severc record of voting rights abuses. Left to their own accord, officials with a history of abusing people's voting rights are not likely to police themselves. Indeed, the record indicates that most abuses recorded by the DOJ have occurred in precisely those jurisdictions with the worst history of abuse. If an analysis were to focus on just Alabama, Georgia, Louisiana,

208. For examples of these arguments, see, e.g., South Carolina v. Katzenbach, 383 U.S. 301 (1966) (where South Carolina and a number of other states objected to the burden Section 5 placed on states), and Lopez v. Monterey County, 525 U.S. 266 (1999) (where California challenged as an incursion into state authority the federal government's refusal to allow Monterey County to implement a statewide voting change).

209. See, e.g., Katzenbach, 383 U.S. at 359-60 (Black, J., dissenting) (invoking images of Southern states as "conquered provinces" foreed to "entreat federal authorities in far-away places for approval of local laws").

210. See, e.g., Bd. of Trs. v. Garrett, 531 U.S. 356, 373-74 (2001); United States v. Morrison, 529

U.S. 598, 626-27 (2000); City of Boeme v. Flores, 521 U.S. 507, 518 (1997). 
Missouri, North and South Carolina, Texas, and Virginia, these eight states (out of the sixteen covered either in part or in whole) would account for 563 out of 599 (almost 94\%) of all objeetions entered by the DOJ to block proposed changes. ${ }^{211}$ Notably, each state that is covered either in part or in whole has had at least one objection entered against it since the last reauthorization. ${ }^{212}$ The correlation between past history of abuse and present violations confirms the accuracy and appropriateness of Section 5's targeted approach.

Second, the fact that thousands of voting changes are still submitted annually for review indicates that in covered jurisdictions-those with a history of voting discrimination-there continue to be multiple opportunities for mischief on the part of election officials and legislatures. For example, jurisdictions switch from single-member to at-large districts, change the location of polling places or change polling hours, and annex or de-annex parts of other jurisdictions. All of these changes can operate as barriers to minority voting. Further, the decennial census allows state legislatures to redistrict evcry ten years based upon population changes. ${ }^{213}$ Redistricting - the redrawing of voting precinct lines based upon population-creates opportunities to dilute minorities' votes in an impermissible manner. Thus, the chance for continued exclusion argues for continued vigilance by the federal government, something that is only possible if Section 5 is reauthorized.

Third, Section 5's opponents argue that compliance with the provision is unduly burdensome on the states. Preclearance is indeed a costly and cumbersome process. Each time that a covered jurisdiction wants to make a voting change (no matter how small) it must either submit it to the DOJ or sue for declaratory judgment in the federal district court for the District of Columbia. If a covered jurisdiction chooses to submit the change for DOJ review, the jurisdiction bears the burden of showing that its changes will not have the purpose or effect of denying or abridging the right to vote. To do so, a jurisdiction may be forced to hire counsel to help it navigate the process and experts who can show through the use of statistics and other data that the change does not have the purpose or effect of abridging or denying the right to vote. In addition to the financial costs, the laborious process will consume staff time and energy. Alternatively, a covered jurisdiction can file a suit seeking declaratory judgment that the change will not have the purpose or effect of abridging or denying the right to vote. Similarly, this process requires the jurisdiction to expend substantial resources and time.

211. Objections, supra note 195.

212. Id.

213. U.S. CONST. art. I, § 2, cl. 3. 
The burden on jurisdictions to comply with Section 5's provisions does not, however, undermine the argument for the reauthorization of the provision. Indeed, the burden on states was intentional: It was intended to motivate jurisdictions to bail out, which they could do by maintaining an abuse-free record. There have been relatively few successful bailout suits, ${ }^{214}$ however, and this low rate of bailout success indicates that there have been ongoing violations and thus a continued need for Section 5 . While some might suggest that jurisdictions do not perceive the need to bailout since they are not discriminating, this argument is unpersuasive. States' rights advocates cannot, on the one hand, complain that preclearance places an unacceptable burden on state/local entities and, on the other hand, assert that covered jurisdictions are not seeking to bail out of the preclearance requirement because they are confident that their changes are compliant and will be precleared by the DOJ.

With regard to the separation-of-powers objection, since Boerne and recent cascs have indicated that Congress was within the scope of its power to enact the Act, arguments that Congress is exceeding its constitutional authority should fail. However, Congress should be mindful of the limitations imposed by Boerne and its progeny when reauthorizing Section 5. Indeed, Congress might use Justice Kennedy's majority opinion in Boerne as a blueprint for ensuring that a reauthorized Section 5 will meet the Court's congruence-and-proportionality test. Among other things, Congress should consider maintaining a sunset provision that limits the length of the reauthorization because such a provision has becn one of the key characteristics distinguishing Section 5 from disapproved statutes. ${ }^{215}$ The length of the reauthorization period may also be a significant factor. As has been noted, the first three reauthorization periods were relatively short (1965-1970, 1970-1975, and 1975-1982) while the most recent reauthorization was for twenty-five years. Congress will need to balance the need for a strong and stable voting rights protection regime with the benefits of shorter, more flexible periods. ${ }^{216}$ Additionally, Congress might consider altering its coverage formula to focus the efforts of the DOJ more effectively and to demonstrate to the Court that it is limiting the application of the provision. ${ }^{217}$ For example, Congress could limit Section 5's coverage

214. See supra notes 86 and 175 and accompanying text.

215. See City of Boerne v. Flores, 521 U.S. 507, 533 (1997).

216. See infra Part 1II.C.2 (discussing how reauthorization provides opportunities for Congress and the Court to "dialogue" regarding the basis and scope of Section 5).

217. City of Boerne, 521 U.S. at 533. Additionally, Congress might consider altering the coverage formula to account for the move of minorities to different parts of the country. For example, the Latina/o population has begun to move in significant numbers to states not traditionally thought of as diverse, sueh as those in the Midwest. See, e.g., Sylvia R. Lazos, "Latina/o-ization" of the Midwest: Cambio de Colores (Change of Colors) as AgroMaquilas Expand into the Heartland, 13 BERKELEY LA RAZA L.J. (forthcoming 2003) (discussing the skyrocketing population growth of Latinas/os in Midwestern states). Such an expansion of Section 5's coverage would be within the spirit 
to those jurisdictions which have had objections entered against them in the last twenty years. ${ }^{218}$ Lastly, Congress might eonsider altering the bailout provision to ease the hurdles that must be overcome before a covered jurisdiction can opt out of coverage. However, it should be underscored that Congress must not water down Section 5's protections in an effort to gain approval by the Court-that would be a Pyrrhic victory.

The following sections set forth two arguments for reauthorization. First, Section 5 should be reauthorized because there is ample evidence that race-based voting discrimination persists. This evidence is critical to the determination of congruence and proportionality under Boerne because it shows what constitutional violations Congress is seeking to remedy and provides the context for Section 5's efforts to deter future violations. Second, Section 5 has symbolic value to minority voting populations, who have come to rely on its protections.

\section{Ongoing Need for Strong Voting Rights Protections: The Substantive Argument for Reauthorization}

This section discusses five reasons that the Act should be reauthorized: the number of changes submitted for review; the number of objections entered by the DOJ; the probability of noncompliance; the limited success of bailout suits; and changes in minority populations. First, analysis of the Section 5 changes submitted to the DOJ for review indicates that Section 5 is still a necessary tool for preventing race-based voting discrimination. In the first twenty-five years of the Act (1965-1989) 168,215 Section 5 changes were submitted to the Attorney General for preclearance. ${ }^{219}$ In the next ten years (1990-1999) another 167,801 changes were submitted. Looked at in another way, an average of 16,780 changes have been received per year for the last ten years compared to an average of 6,728 per year for the first twenty-five years of the Act. ${ }^{220}$ The substantial

of the Act but may run afoul of the Court since many districts experiencing an influx of minorities do not have a historical record of voting discrmination. It should be noted that voters suffering discrimination in uncovered jurisdictions still may be able to make a claim under the other sections of the Act.

218. It is important to note that even if coverage was thus limited, the majority of states that are currently covered would remain covered. Objections, supra note 195. However, pursuant to changes adopted during the 1982 reauthorization, counties within otherwise covered states might be able to successfully bail out if they could show that they had not adopted changes violating Section 5 . In the 1982 reauthorization, Congress added the phrase "or political subdivision" to the bailout provision. 42 U.S.C.A. $\$ 1973$ (b) (2000). Where the pre-1982 provision stated that to bail out a covered jurisdiction would have to prove that "no such test or device has been used within such State for the purpose or with the effect of denying or abridging the right to vote on account of race or color," the new provision stated that to bail out a covered jurisdiction would have to prove that "no such test or device has been used within such State or political subdivision for the purpose or with the effect of denying or abridging the right to vote on account of race or color." Id. (emphasis added).

219. Section 5 Changes, supra note 72.

220. Id. 
number of changes submitted for review indicates that there is abundant opportunity for mischief and that an oversight mechanism continues to be necessary. ${ }^{221}$

Second, the Attorney General has continued to enter objections to numerous changes submitted for preclearance. ${ }^{222}$ Entering objections means that, upon submission of proposed changes, the Attorney General found that "such qualification[s], prerequisite[s], standard[s], practice[s], or procedure[s] ... have the purpose [or] the effect of denying or abridging the right to vote on account of race or color." 223 In the almost forty years since the Act's passage in 1965, the DOJ has entered over one thousand objections in response to submitted changes that, in the DOJ's judgment, had the purpose or effect of denying or abridging the right to vote on account of race or color. ${ }^{224}$ As Figure 2 shows, since the 1982 reauthorization, the DOJ has continued to enter a significant number of objections, indicating that violations of voting rights continue. The fact that many of these objections were entered under Republican administrations (19801992) further indicates the serious nature of the violations. Since the Republican party has traditionally championed states' rights, it is unlikely that a Republican-led DOJ would impose on state/local authority without clear evidence of violation of the law. The record of objections not only supports the argument for reauthorization but also supplies proof that Section 5 is congruent and proportional.

\section{Figure 2: Objeetions Entered by the Attorney General ${ }^{25}$}

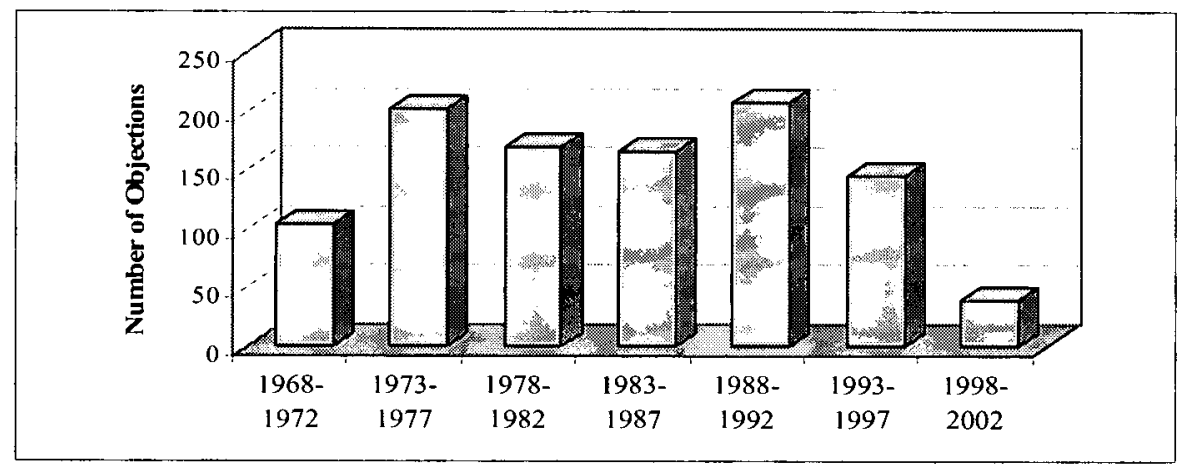

221. $I d$.

222. For examples, see infra note 242.

223. See 42 U.S.C. $\$ 1973$ e (2000).

224. Objections, supra note 195.

225. During the early part of the 1998-2002 period, there were several years where fewer than ten objections per year were entered by the DOJ, an anomalously low number of objections. In the later part of the period, there was an upswing in objections entered. Specifically, in 2002 there were 17 objections entered. Objections, supra note 198. 
Third, the foregoing analysis of changes submitted and objections entered probably underestimates the extent of violations because it does not factor in noncompliance (when jurisdictions fail to submit their changes for DOJ review). Smaller jurisdictions-townships, municipal water districts, or counties, for example-might not submit their changes for Section 5 review if they think that submission might result in the rejection of their changes. These smaller entities know that, compared to a statewide jurisdiction, their noncompliance is less likely to be noticed by the DOJ. Their nonsubmission essentially shifts the burden to the DOJ or to excluded voters to challenge the changes. Thus, by doing nothing, these jurisdictions can gamble that the DOJ will not have the resources to ferret out noncompliance and that private citizens and groups will do nothing. Lopez $v$. Monterey County ${ }^{226}$ was an example of such noncompliance. Monterey County, a covered jurisdiction, had implemented a series of changes to judicial elections in the county without obtaining preclearance from the Attorney General. Since there is no reliable way to measure how much noncompliance exists, it is difficult to estimate its prevalence in any substantive way, but it is important to note that during the 1982 reauthorization hearing, voting rights advocates gave testimony about widespread noncompliance in states like Texas. ${ }^{227}$

Fourth, the lack of successful bailout suits indicates the continued need for Section 5. Undcr Section 4 of the Voting Rights Act a covered jurisdiction can "bail out" from coverage through an action for declaratory judgment in the district court for the District of Columbia. ${ }^{228}$ In order to prevail in the suit, a covered state must prove the following: that in the ten years prior to filing the action for declaratory judgment, it has not used a test or device that has a discriminatory purpose or effect; that no court has

226. 525 U.S. 266 (1999).

227. Extension of the Voting Rights Act: Hearings Before the Subcomm. on Civil and Constitutional Rights of the House Comm. on the Judiciary, 97th Cong. 929-33 (1982) (statement of Joaquin Avila, Associate Counsel, Mexican-American Legal Defense and Educational Fund (MALDEF)). Mr. Avila testified about the "large number of voting problems and voting discrimination complaints that we received from Texas." Id at 929 . He also testified about

"devices [in Texas] that have been implemented after the 1975 extension of the [Act] . . the most egregious and the most significant [of which] are the obvious attempts to gerrymander the Chicano community in many parts of Texas. In order to combat this obvious attempt, these obvious, blatant gerrymanders, we need Federal oversight.... [W]e found that approximately 51 counties in Texas which contained Chicano populations ranging in percentage from the high 70 's to 80 's to as low as the low 20 's, 25 percent, did not contain a single Hispanic commissioner on the county commissioners court, which is the governing body for each of the countics."

Id. at 930. Avila also mentioned other cxamples of voting discrimination: many counties had not redistricted since 1970, others had never redistricted since their creation; voters were urged to vote for a dead candidate rather than vote for the only remaining candidate, a Latino; voting advocates werc thrcatened because of their effort to combat discrimination; a city adopted a discriminatory system, and upon receiving a DOJ objection, went ahcad with implementing the system until a MALDEF-sought injunction prevented them from doing so. Id. at 930-33.

228. 42 U.S.C. $\$ 1973 b(2000)$ 
issued a final judgment against the city or county for voting discrimination; that there has been full compliance with Section 5 of the Act, including the preclearance of voting changes before they are implemented; that the Attorney General has not issued an objection to a proposed voting change; and that no declaratory judgment has been denied under Section 5 by the district court for the District of Columbia. ${ }^{229}$ In addition to these factors, if a city or county within a covered state wants to bail out from coverage, it must also show that it has not engaged in other discriminatory practices prohibited by the Act, unless the behavior was promptly corrected and was not repeated; it must show that it has taken constructive steps to increase minority access to the political process; and it must show that there has been an increase in minority political participation. ${ }^{230}$ Given the large number of cities, counties, and states that are covered by Section 5, there have been relatively few successful bailout suits ${ }^{231}$ even though the 1982 amendments to the Act (allowing cities and counties to bail out and creating a twenty-five year reauthorization cap) were intended to encourage striet compliance and early bailout as a way for jurisdictions to avoid Section 5's administrative burdens. ${ }^{232}$

Fifth, changing minority demographics indicate a need for Section 5's reauthorization, quite possibly its alteration, and perhaps even its expansion. ${ }^{233}$ Originally, the Act was passed to protect the voting rights of Blacks in majority White jurisdictions that had resisted, often violently, efforts to enfranchise the Black minority. ${ }^{234}$ However, the most recent census reveals that Latinas/os have become the largest minority in the United States. ${ }^{235}$ Not only have the numbers of Latinas/os grown, but they have changed the

\section{Id.}

230. Id.

231. See, e.g., Section 5 Requirements, supra note 64, at n.5, 6, 8; McDonald, supra note 53, at 48$49 \mathrm{n} .282-86$. In the almost forty years of Section S's existence, fewer than ten jurisdictions have been able to successfully bail out. The State of Alaska was originally covered under the Act in 1965, but successfully bailcd out in 1966, the only fully covered state to successfully bail out. Alaska, however, was then recaptured by the coverage formula in the 1975 reauthorization of Section 5 and remains covercd today. The coverage formula contained within the 1970 amendments to the Act resulted in the partial coverage of ten states: Alaska (which was later fully covered under the 1975 amendments to the Act), Arizona, California, Connecticut, Idaho, Maine, Massachusetts, Ncw Hampshire, New York, and Wyoming. Half of these states have since bailed out: Connecticut, ldaho, Maine, Massachusetts, and Wyoming. Section 5 Requirements, supra note 64 , at $\mathbf{n} .6$. In addition, under amendments to the bailout provision adopted in 1982 that allowcd counties within covered states to pursue bailout suits, three additional jurisdictions have bailed out: the City of Fairfax, Virginia (in Virginia, independent eities are the equivalent of counties), as well as Frederick and Shenandoah Counties, Virginia. Id. at n.7.

232. McDonald, supra note 53, at 53.

233. See supra note 217 for a discussion of the potential need to expand Section 5's coverage formula as minority populations move into jurisdictions that had not been considered racially diverse before.

234. See supra Part 1.A.

235. U.S. Census Bureau, Census 2000 Brief: Overview of Race and Hispanic Origin, Table 1, T.3 \& 10 (March 2001), available at http://www.census.gov/prod/2001 pubs/c2kbr01-1.pdf. 
racial balance in many jurisdictions, which either had no racial minority before ${ }^{236}$ or had a different mix of races (e.g., Black and White). These demographic changes complicate efforts to apply the Act to protect minority voters because the Act's original framework was designed to protect a Black minority in a majority White jurisdiction. As minorities move into new communities in different parts of the country, there will almost certainly be friction not only between Whites and Latinas/os but also between established communities of racial minorities and the recently arrived minority group, who represents new electoral "competition." ${ }^{237}$ This competition and perception of a zero-sum game will increase the likelihood that established communities (White and non-White) may resort to finding ways to maintain their power and to prevent the newcomers from the full enjoyment of their voting rights. Section 5's original framework may need to be reconceptualized in this multiethnic context. The 2007 reauthorization hearings will present a valuable opportunity to develop new tools for addressing these challenges.

In sum, these substantive reasons underscore the need for Congress to reauthorize Section 5. The record of submissions, objections, noncompliance, unsuccessful bailout suits, and population shifts shows that, even thirty-eight years (I965-2003) after the adoption of the Act and long after termination of those practices that were the initial targets of the Act (overt barriers such as literacy tests, voter intimidation, etc.), practices continue which undermine racial minorities' right to vote. These contemporary examples of voting rights abuses also bolster the modern record of violations that, according to the Boerne Court, distinguished the Act from other Iegislation that did not meet the congruence-and-proportionality test. ${ }^{238}$ Because

236. The 2000 Census showed that the population of Latinas/os is shifting to different parts of the country. Betsy Guzmán, U.S. Dep't of Commerce, The Hispanic Population: Census 2000 BRIEF (2001), available at http://www.census.gov/prod/2001 pubs/c2kbr01-3.pdf (issued May 2001). In 1990, Latinas/os represented $7.4 \%, 2.9 \%$, and $7.9 \%$ of the Northeast, Midwest, and South respectively. ld. But in 2000, Latinas/os in those same areas represented $9.8 \%, 4.9 \%$ and $11.6 \%$ of the population. ld.

237. Among the differences between Blacks and Latinas/os are the fact that Blacks tend to vote rather reliably as a bloc, meaning that most of the community tends to express voter preferences together. Latinas/os are not as homogenous for a varicty of reasons. First, "Latino" is a pan-ethnic label that obscures differences between Mexicans, Cubans, Guatemalans, Puerto Ricans, etc., of which there may be many. Additionally, even focusing on a subgroup like Mexican-Americans is further complicated by the fact that there may be wide voter-preference differences that may arise out of variations in immigration status, language, assimilation level, etc. Another complication is that courts may be increasingly hesitant to view Latinas/os as dcserving of vigorous protection under the Act in areas where Latinas/os are becoming a majority of the population (a majority-minority district), even though districting and other voting changes may stymie Latinas/os' ability to have a meaningful voter preference realized. See, e.g., Cano v. Davis, 211 F. Supp. 2d 1208 (C.D. Cal. 2002) (rejecting a challenge to California's decision not to draw Latina/o majority districts in its redistricting process after the 2000 Census). Lastly, a diverse jurisdiction that is made up of populations of Blacks, Latinos, and other minorities, as well as Whites may present problems when trying to apply the Act's provisions.

238. City of Boerne v. Flores, 521 U.S. 507, 530 (1997). 
congruence and proportionality is determined by comparing the remedy to the "evil presented," examples of ongoing abuses are critical in an effort to withstand a constitutional challenge. ${ }^{239}$

\section{Public Reliance: The Symbolic Argument for Reauthorization}

In addition to the formidable substantive reasons for reauthorizing Section 5 , the need for Congress to demonstrate a strong political commitment to vigorously protecting minorities' voting rights offers a parallel, yet distinct, rationale for reauthorization. In light of the presidential voting debacle in Florida in 2000, the conclusions reached by the U.S. Commission on Civil Rights regarding barriers to participation by minority voters, ${ }^{240}$ and the ongoing post-September 11 discussion implicating issues of citizenship, civil rights, and political participation, there could not be a more important time for political institutions to reaffirm the importance of preventing racial discrimination in voting.

Allowing Section 5 to lapse would be a significant blow to minority communities because it would signal to many in those communities that Congress was no longer determined to be vigilant in its protection of minorities' right to vote and no longer interested in pursuing a vigorous campaign against voting rights abuses. ${ }^{241}$ Minorities' alarm would be heightened because of the evidence of significant abuse that Congress has been presented with in the recent past. Consider the congressional hearings surrounding the I982 reauthorization of the Act. Despite the obstacles-a President hostile to extending and strengthening the Act and a Congress that was not convinced of the need for reauthorization-congressional hearings regarding the continued existence of racial discrimination by jurisdictions turned the tide. The public support for reauthorization and Congress's astonishment at the extent of discrimination ensured the Act's extension. Then, as now, there was a realization on the part of minorities, Congress, and the public at large that the passage of time between the Act's enactment and the consideration of reauthorization in 1982 had not lessened the need to keep a protective watch over the voting rights of vulnerable minorities. Instances of voting rights abuses were still occurring. The subtle and sophisticated methods currently in use today to disempower

\section{Id.}

240. U.S. Comm'n on Civil Rights, Voting Irregularities in Florida During the 2000 Presidential Election, at http://www.usccr.gov/pubs/votc2000/report/main.htm (June 2001).

241. For example, in the mid-1990s, an urban myth began to circulate that Blacks would become disenfranchised if the Act expired in 2007. Conflating the constitutional guarantees of the Fifteenth Amendment with the statutory provisions of the Act, some Blacks began to phonc the DOJ to express their concern that they would be shut out of the political process altogether. U.S. Dep't of Justice, Civil Rights Division, Voting Section, Voting Rights Act Clarification, at http:/www.usdoj.gov/crt/voting/ misc/clarify3.htm (posted April 2, 1998) [hereinafter Voting Rights Act Clarification]. This episode illustrates Blacks' persistent fear that the right to vote, realized only recently, is still ephemeral and subject to termination. 
minority voters are no less insidious than the blatant barriers that convinced Congress to pass the original Act. ${ }^{242}$

Conversations exploring the meaning and contours of citizenship along with debates about the limits of civil rights have become increasingly important in a post-September 11 world. As such, many things that implicate political rights and their enforcement are being revisited and reexamined. At a time when the nation is engaging in such a critical enterprise, it is important that minority voters not be closed out of the dialogue. As always, the exercise of the right to vote is how the nation will determine its course. If minority voters are to have any real input into that national conversation, let alone feel that they have had meaningful input, it is incumbent upon Congress to reauthorize Section 5, which has been a symbol of voting rights protections for the last four decades.

\section{Section 5 's Constitutionality After Reauthorization}

If Congress reauthorizes Section 5 in 2007, affected jurisdictions and/or states' rights advocates will almost inevitably challenge the reauthorization as unconstitutional. Of the potential challenges discussed thus far, the post-reauthorization challenge poses the greatest threat to Section 5 , principally because the timc limit will have been extended. There are three reasons why any such challenge to a reauthorization should be rejected by the courts.

First, the post-reauthorization Section 5 should still meet the requirements of Boerne's congruence-and-proportionality test. As with a pre-2007

242. See supra note 200. A quick perusal of recent objections entered by the DOJ provides an sense of these types of barriers and abuses. U.S. Dep't of Justice, Civil Rights Div., Voting Section, Section 5 Objection Determinations, at http://www.usdoj.gov/crt/voting/sec_5/obj_activ.htm (last revised Dec. 31, 2002). Between the months of August and December 2002, the DOJ entered objeetions to redistricting plans in Georgia, Lousiana, South Carolina, and Texas. In each instance, the objection letter sent to the covercd jurisdictions explained that the proposed redistricting plans would reduce the number of districts in whieh minority voters could elect someone of their choice. In a letter to the Marion County School District in Marion County, Georgia, for example, the DOJ explained that a benchmark districting plan (a plan developed by the DOJ for comparison purposes) would have resulted in three "safe" districts, where Blacks would make up more than $55 \%$ in each district, Letter from Ralph F. Boyd, Jr., Assistant Attorney General, U.S. DOJ Civil Rights Division, to Wayne Jerrigan, Phillip Hartley, and Cory O. Kirby, Counsel for Marion County School District (Oct. 15, 2002), at http://www.usdoj.gov/crt/voting/sec_5//tr/l_101502.htm. In Marion County's proposed plan, by contrast, Blacks would make up a significant percentage in only one district and barely more than $50 \%$ in a second. Annexations pose another potential barrier to minority voting rights. Annexations occur when a covered jurisdiction absorbs an adjoining city or suburb and as a result lowers the percentage, and thus the voting strength, of minority voters. In a letter to the City of Clinton in South Carolina, the DOJ objected to the city's annexation plan. Letter from Ralph F. Boyd, Jr., Assistant Attorney General, U.S. DOJ Civil Rights Div., to C. Samuel Bennett II, City Manager, City of Clinton (Dec. 9, 2002), at http://www.usdoj.gov/crt/voting/sec_5/ltr/1_120902.htm. The DOJ noted that the annexation would result in the reduction of the Blaek population from $59 \%$ of a ward (akin to a voting district) to barely $50 \%$. The Department determined that the city, in so doing, would effectively eliminate a district where Blacks could elect the candidate of their choice. 
challenge, the first question would be whether the remedy selected demonstrated a congruencc between the means used and the end to be achieved, and the second question would be whether the remedy was proportionate to the unconstitutional behavior it was dcsigned to remedy or prevent. Several factors that the Court used to distinguish the Act from invalid legislation will continue to exist. Among those factors is the modern history of voting rights abuses that the DOJ has continued to document. ${ }^{243}$ Additionally, pursuant to reauthorization, Congress would hold hearings at which voting rights advocates could testify. As in the hearings before the 1982 reauthorization, we could expect testimony about new forms of voting rights abuse. Another distinguishing factor the Court pointed out in Boerne that would continue to exist would be the limited scope of Section 5: The provision would apply to only those jurisdictions with the longest and most pervasive history of discrimination, and Section 5's scope could be even more focused by a reworking of the coverage formula. ${ }^{244}$ Additionally, any reauthorization of Section 5 would almost certainly include bailout and sunset provisions, both of which the Court pointed to as distinguishing the Act from legislation that ran afoul of the congruence and proportionality test. There is no reason to believe that a reauthorization of Section 5 would change any of those distinguishing factors the Court identified as recently as 2001 . $^{245}$

Second, there has been a unique "constitutional dialogue" between Congress and the Court regarding the scope and meaning of the Act. This dialogue has continually enlarged the voting rights norms as expressed in Section 5 of the Act. Building on a concept outlined by Professors Robert C. Post and Reva B. Siegel in a recent article, ${ }^{246}$ this Comment argues that an engagement between Congress and the Court, unique to the Act, took place, resulting in the current broad voting rights framework. The results of this decades-long engagement should not be disturbed lightly.

Third, the principle of stare decisis argues strongly in favor of upholding Section 5, especially since there is reliance by minority voters and the public at large, both of whom have internalized important judge-announced norms. Minority voters have not only relied on the Act generally to guarantee their ability to fully participate as citizens, but they have also relied on Section 5 specifically to ensure that the federal government has the ongoing flexibility to protect their right to vote against the innumerable machinations of hostile or unthinking state or local governments. The Court's opinion in Planned Parenthood v. Casey stated that a Court should be careful when considering overturning a case, especially one that involves an

243. See supra Figure 2, at 807, and text accompanying notes 222-24.

244. See supra Part III.B.1.

245. Bd. of Trs. v. Garrett, 53 I U.S. 356, 373-74 (200I).

246. Post \& Siegel, supra note 30. 
"intensely divisive controversy" and where a whole generation had relied on the precedent and structured its behavior accordingly. ${ }^{247}$ It is incumbent upon the Court to respect the precedent of broadly sweeping voting rights protections.

\section{Applying Boerne's Congruence-and-Proportionality Test to the Reauthorization of Section 5}

Before applying the Court's congruence-and-proportionality test to a reauthorized Section 5, it is first necessary to outline what a reauthorized Section 5 might look like. As discussed in Part IIl.B.I, Congress might consider a number of changes or provisions, assisted by the use of Justice Kennedy's Boerne decision as a roadmap, in an effort to construct a congruent and proportional Section 5.

Among the possible changes that could be contemplated are: (1) reworking the coverage formula to only include those jurisdictions with objections entered against them since 1982; (2) shortening the sunset provision of Section 5 to maximize legislative flexibility and to ensure a tight fit between problem and remedy; and (3) easing the bailout provision. This Comment assumes that some, if not all, of these changes might be adopted in a reauthorized Section 5. In addition, as discussed in Part III.B.I and III.B.2, any reauthorization would be preceded by congressional hearings in which voting rights advocates and voters would testify as to the ongoing need for Section 5 protection owing to the continuing nature of voting rights abuses.

The Boerne test for determining whether legislation falls within the scope of Congress's Fourteenth Amendment enforcement power requires an inquiry into whether there is a "congruence and proportionality between the injury to be prevented or remedied and the means adopted to that end." ${ }^{248}$ Congruence is determined by an agreement or correspondence "between the means used and the ends to be achieved. The appropriateness of remedial measures must be considered in light of the evil presented."249 The proportionality prong of the test looks at whether a relationship of comparative magnitude exists between remedies proposed and the "supposed remedial or preventative objective [so that it can be] understood as response to, or designed to prevent, unconstitutional behavior." 250

In the case of a reauthorized Section 5, no meaningful change in circumstance or remedial device would have been worked since the Court's recent and repeated validation of the Act as an example of congruent and

247. 505 U.S. $833,866-67$ (1992).

248. City of Boerne v. Flores, 521 U.S. 507, 520 (1997).

249. Id. at 530 .

250. Id. at 532 . 
proportional legislation. ${ }^{251}$ With respect to the congruence of a reauthorized Section 5, any future Court should hearken back to Boerne, where the Court favorably compared the Act to the RFRA because of the modern examples of voting rights abuses that motivated Congress to pass the Act. ${ }^{252}$ Similarly, modern examples of voting rights abuses continue to accumulate today. As illustrated in Figure 2, the number of objections entered to submitted voting changes - changes that were determined to have the purpose or effect of denying or abridging minorities' right to vote-has remained relatively constant throughout the life of the Act. Indeed, there were more objections entered in the third decade of the Act's existence than in the first or second decade. ${ }^{253}$ If the 1982 reauthorization hearings are any indication, additional voting rights abuses will surely be brought to light during the 2007 reauthorization process. Voting rights advocates and civil rights organizations, which would find it prohibitively expensive to constantly catalogue abuses, will certainly begin to gear up as 2007 nears in an effort to present Congress with a picture of how far voting rights protection still has to go. Additionally, Congress, when passing civil rights legislation in the post-Boerne era, has made increasing efforts to create a record that would demonstrate to the Court a congruence between the remedy and the injury. ${ }^{254}$ It is likely, therefore, that Congress would make a similarly exhaustive effort to document the ongoing problems in the area of voting rights.

An inquiry into congressional authority to reauthorize Section 5 would then turn to an examination of its proportionality. As before, it is instructive to begin by looking at those characteristics the Court highlighted when describing the Act as proportional. The Boerne Court described the Act's prophylactic remedies as "appropriate when there is reason to believe that many of the laws affected ... have a significant likelihood of being unconstitutional." ${ }^{255}$ The Court acknowledged there that the coverage formula, which limited the scope of Section 5 to those jurisdictions with a demonstrable history of racial discrimination, meant that there was likely to be a high proportion of unconstitutional voting changes. A reauthorized Section 5 would not change this proportionality analysis. Coverage would still be limited to those jurisdictions with long (and continuing) histories of racial discrimination. And the remedies would still be aimed at voting changes that have a significant likelihood of being unconstitutional.

251. See supra note 29.

252. City of Boerne, 521 U.S. at 530.

253. See Objections, supra note 195 and Figure 2, at 807 . There were 306 objections entered between 1968-1977, 338 between 1978-1987, and 353 between 1988-1997.

254. See, e.g., Bd. of Trs. v. Garrett, 531 U.S. 356, 377, 389-424 (2001) (Breyer, J., dissenting) (noting that Congress had compiled a "vast legislative record" and listing thirty-five pages of congressional documentation of examples of discrimination).

255. City of Boerne, 521 U.S. at 520. 
The proportionality inquiry also examines the ways in which the remedy is tailored to ensure a tight fit between injury and remedy. Several characteristics of the Act were highlighted in Boerne as ensuring such a proportional relationship. The Court pointed out that: Section 5 does not apply nationally but is limited to certain discrete jurisdictions with histories of discrimination; the Act does not affect all laws but only targets a small class of laws, those affecting voting; Section 5 contains bailout provisions which allow jurisdictions to avoid preclearance burdens by demonstrating that they have been free of discrimination in their voting changes; and Section 5 contains a sunset provision after which it lapses unless Congress reauthorizes its provisions. ${ }^{256}$ While the Court clarified that an enforcement provision does not require "termination dates, geographic restrictions, or egregious predicates," it also noted that "limitations of this kind tend to ensure Congress' means are proportionate to ends legitimate under [the Fourteenth Amendment]. ${ }^{257}$ All of these limitations would exist in a reauthorized Section 5.

Coverage would still be limited to those political entities that have a history of racial discrimination in the area of voting. Indeed, a tighter fit could be created by reworking the coverage formula to exclude some jurisdictions that have maintained a lengthy record free of discrimination. In addition, Section 5 would continue to affect only a discrete class of state laws - those that concern voting. Bailout provisions would allow jurisdictions that prove they are free of discrimination to avoid the preclearance requirement. Even preclearance itself is no hindrance to the adoption of voting changes once the Attorney General or the District Court for the District of Columbia has determined that the changes would not violate Section 5. Lastly, a sunset provision would still be a part of a reauthorized Scction 5, meaning that absent new congressional hearings and a deeision to reauthorize again in the future, Section 5 would expirc of its own accord. As problems disappear and the situation improves, support for the Act would naturally recede and Congress could allow Section 5 to expire once it was no longer needed. All of these provisions, which would presumably continue to exist in a reauthorized Section 5, would serve to ensure that it continued to be a proportional response to the evil of voting rights violations.

\section{Constitutional Dialogue Between Congress and the Court}

In their article, Equal Protection by Law: Federal Antidiscrimination Legislation After Morrison and Kimel, Professors Post and Siegel introduce the notion of a constitutional dialogue between the legislature and judiciary through which Congress and the Court determine the parameters

256. Id. at 533 .

257. Id. 
of antidiscrimination laws and the bases for their enactment. ${ }^{258}$ Post and Siegel analyze the development of antisegregation and antidiscrimination law in the 1960s and conclude that the Court and Congress partnered to ensure that Congress would have the authority under the Commerce Clause to enact civil rights legislation: ${ }^{259}$ "Social activism had forced the question of discrimination by private actors to the top of the national agenda, and Congress had responded with major legislation to address the problem. This legislation was ratified by the Court. . ."260

The Court's decision in Brown v. Board of Education ushered in a new era of cooperation between the two branches to ensure the full implementation of the Fourteenth and Fifteenth Amendments: "[T]he Court established a relationship with Congress that was fluid and dynamic.... This institutional relationship enabled the Court to interpret the Equal Protection Clause in a manner that was attentive to evolving and contested social norms." 261 it was this relationship and the willingness of both branches to view themselves as engaged in a partnership to advanee principles of equality that made the civil rights legislation coming out of this era so powerful and effective. This cooperative engagement, which Post and Siegel term "institutional ecology," social conceptions of equality shaped and guided each other ${ }^{263}$ It was in this way that the institutional advantages of each branch were able to reinforce and amplify each other to move the civil rights agenda forward and react to social and legal change in a way that each branch on its own could not have done.

As with the interbranch conversation that surrounded the enactment of earlier civil rights legislation, such as the Civil Rights Act of 1964, there was also, and continues to be, an ongoing conversation regarding the basis and the scope of the Act. The parameters of the Act, like those of the Civil Rights Act of 1964, have been determined through a dialogue between Congress and the Court, which continually reified and expanded the statute's provisions. Applying Post and Siegel's framework, this Comment

258. Post \& Siegel, supra note 30 , at 494.

259. Id.

260. Id. at $496-97$.

261. Id. at 446. See supra note 21 and accompanying text (explaining that the Fourteenth and Fifteenth Amendments' enforcement powers are coextensive).

262. Post \& Siegel, supra note 30 , at 446.

263. In constitutional law, this dialogue seems unique to Equal Protection Clause jurisprudence. Id. Even though Congress and the Court certainly have gone baek and forth with legislative and judicial pronouncements in other areas, only in the area of antidiscrimination values have the two branches acted in eoncert in order to fully explicate the scope of legal norms. This cooperation began with Brown v. Board of Education, 347 U.S. 483 (1954), when the two branches gave life to the Fourteenth Amendment, which had largely laid fallow since the Civil Rights Cases, 109 U.S. 3 (1883), seemed to render the Fourteenth Amendment a dead letter at the turn of the century. Since Brown. when the Court has acted to protect racial minorities from discrimination, it has relied on Congress to win majority support for its decisions. Post \& Siegel, supra note 30 , at 446. 
elucidates the role that interbranch dialogue has played in the development of the Act.

The interbranch dialogue in the voting rights area was initiated by Congress's hearings on widespread voting discrimination in the South and the subsequent passage of the Act in 1965. ${ }^{264}$ The content of the hearings and the sweeping language of the Act clearly communicated Congress's intent to condemn electoral abuses and to arm the DOJ with strong enforcement tools. A year after this initial step, the Court responded, continuing the dialogue with its broad interprctation of the Act's provisions in South Carolina v. Katzenbach. ${ }^{265}$ That case was remarkable not only for its expansive interpretation of the Act's provisions and for its deferential stance toward Congress's constitutional enforcement power, but also for the Court's total rejection of South Carolina's arguments against the Act. ${ }^{266}$ The Court followed its decision in South Carolina v. Katzenbach with Katzenbach v. Morgan. ${ }^{267}$ In Morgan, as in South Carolina v. Katzenbach, the Court gave a broad interpretation of Congress's power to combat discrimination in the area of voting. Thus, after Congress had sct out a remedy for what it felt needed to be done about the problem of voting discrimination, the Court did not merely uphold Congress's solution, it also gave a broad reading to the Act's language. ${ }^{268}$

This interbranch dialogue regarding voting rights was unlike anything surrounding other civil rights legislation. As a point of comparison, consider the dialogue that occurred between the Court and Congress over the state action requirement as a potential barrier to using the enforcement provision of the Fourteenth Amendment to support the Civil Rights Act of 1964. In this example, the Court basically looked the other way (sometimes implying, but not explicitly stating, approval) while Congress seemed to go beyond the state action requirement. ${ }^{269}$ One reason that the Court silently

264. South Carolina v. Katzenhach, 383 U.S. 301, 308-09 (1966) (commenting on Congress's deliberations regarding the Act).

265. 383 U.S. at 308 ("The Voting Rights Act... creates stringent new remedies for voting discrimination... [and] strengthens existing remedies .... We hold that [the Act is] an appropriate means for carrying out Congress's constitutional responsibilities and [is] consonant with all other provisions of the Constitution."). Writing for the majority, Chief Justice Warren analogized the scope of Congress's power under Seetion 5 of the Fifteenth Amendment to its broad powers under the Necessary and Proper Clause. Id. at 326. For a detailed discussion of Katzenbach, see supra Part Il.A.

266. Id. at 325-28.

267. 384 U.S. 641 (1966).

268. Scott Gluck, Congressional Reaction to Judicial Construction of Section 5 of the Voting Rights Act of 1965, 29 Colum. J.L. \& Soc. ProBs. 337 (1996). Gluck notes that "[a] series of Supreme Court rulings handed down in the late 1960's and early 1970's adopted an extremely broad interpretation of the changes to which Section 5 applied." $/ d$. at 340 . In discussing the Court's opinion in South Carolina v. Katzenbach, Gluck explains that it "gave an extremely broad reading to the Act's legislativc history and a wide characterization of congressional objectivcs. The Court made a number of sweeping statements regarding the Act's purpose that... would prove to be extremely important precedent in future Supreme Court eases." Id. at 356.

269. Post \& Siegcl, supra note 30, at $497-501$. 
acquiesced in Congress's actions is that the actions took heat off the Court and prevented the Court from being pressured to abrogate the state action requirement itself. ${ }^{270}$ Thus, the Court was free riding on Congress's expansive definition of its Fourteenth Amendment enforcement power, while not explicitly endorsing or enlarging it. By contrast, in the context of the Act, Congress and the Court have explicitly affirmed each other in pushing farther and farther on congressional enforcement power in their interpretation (by the Court) and amendment (by Congress) of the Act.

The Act's short authorization periods facilitated this process: The initial provisions were set to expire after five years. Those short periods meant that Congress had great flexibility in responding to the Court's decisions regarding the scope and intent of the Act. In 1970 it did just that by extending and broadening the provisions of Section $5^{271}$ and affirming the Court's decisions in the earliest cases. ${ }^{272}$

In the years following those cases and amendments, the Court and Congress continued to engage in a constitutional dialogue. After the 1970 reauthorization and amendments, the Court's opinions expanded the Court's earlier precedents; woven into the language and rationale of the Court were testimony and findings from the congressional hearings from the 1970 extension. Congress, in turn, affirmed the Court's decisions, extending the Act in 1975 and broadening it by again increasing the number of political entities covered by the Act. The Court benefited from Congress's role as a popular legislative body which infused the Court's jurisprudence with ideas that the Court had not yet been willing to

270. Id. at 497-98.

271. Specifically, in the 1970 reauthorization, Congress extended the triggering dates that determined which jurisdietions were covered and brought more political entities within the scope of the Act's provisions. Section 5 Requirements, supra note 64.

272. See Gluck, supra note 268. In discussing the effect of the Court's early decisions on Congress's hearings in 1970, Gluck notes that the uncertainty that marked the 1965 hearings was not apparent in the 1970 hearings, primarily because of judicial or administrative dctcrmination contained in South Carolina v. Katzenbach and Allen v. Board of Elections. Id. at 360 . Indeed, according to Gluck, "There is no doubt that Congress was aware of the implications of the Allen decision; by retaining Section 5 with knowledge of this interpretation and without any changes in the wording, Congress was tacitly endorsing Allen." Id at 369 . The interaction between Congress's and the Court's actions did not end there. After Congress's approval of the Court's broad opinions in South Carolina v. Katzenbach and Allen v. Board of Elections, "courts could not help but notice that Congress approved of the Supreme Court's construction of Section 5 in [these cases]: Congress refused to repeal or weaken Section 5 and rejected all attempts to amend this important section." Id. at 371. Gluck continues on, noting that in light of the Court decisions and Congress's 1970 reauthorizations, the DOJ entered objections that advocated an even broader interpretation than the one contained in Allen. Id. These still broader interpretations were upheld by the Court in two cases, Georgia v. United States, 411 U.S. 526 (1973), and Perkins v. Matthews, 400 U.S. 379 (1971). In upholding the objections, the Court relied not only on the earlier language in Allen but also on the 1965 and 1970 congressional hearings. Gluck, supra note 268 , at 371-75. 
accept. ${ }^{273}$ For Congress, the institutional authority that the Court could bring to bear was valuable in giving the legislation more legitimacy.

One of the few major disagreements between the Court and Congress was resolved through this interbranch dialogue. In I980, the Court decided City of Mobile v. Bolden, ${ }^{274}$ in which a confusing split opinion held that the Fifteenth Amendment and the Act applied only to interference with an individual's right to vote and not to structural discrimination. The Court further held that the Fourteenth and Fifteenth Amendments and Section 2 of the Act required proof of purpose. ${ }^{275}$ This narrowing of the scope of the Act's provisions caused consternation among activists, scholars, and politicians alike. There was concern that Bolden signaled a rollback of the Act's protections and betrayed the central purpose and spirit of the legislation. ${ }^{276}$

Two years after Bolden, in 1982, Congress reauthorized the Act and amended Section 2 to specifically overrule the Bolden decision. The new Section 2 allowed litigants to bring a claim based solely on a showing of discriminatory effect. This reauthorization was perhaps the boldest so far. In addition to overruling the rationale in Bolden, Congress extended the life of the provisions for twenty-five years. In cases after the 1982 extension of the Act, the Court assimilated the new standard and congressional findings and began deciding cases in line with congressional intent as evidenced by the new amendments.

This dialogue between the Court and Congress ensured that both branches of government were able to inform the decisions of the other bodies. A feedback loop was formed whereby the meaning of the Act and Section 5 was clarified by dual efforts to interpret and amend. Indeed, unlike other examples of antidiscrimination legislation where interbranch conversation is found, here there was an ongoing process of mutual reinforcement of the sister branch's position and mutual enlargement of the statute's scope. This dialogue strongly suggests that the Court has been a willing, and vital, participant in the evolution of congressional enforcement power to combat voting discrimination. When the Act was passed, the Court accepted, as a starting assumption, that the authority to pass Section 5 of the Act under Fifteenth Amendment power was an entirely unproblematic notion. ${ }^{277}$ Ncver has a majority of the Court intcrpreted Section 5 to be beyond the enforcement powcr of Congress, nor has Congress balked at

273. Post \& Siegel, supra note 30 , at 518 .

274. 446 U.S. $55(1980)$.

275. Id. at 66 .

276. See, e.g., James U. Blacksher \& Larry T. Menefee, From Reynolds v. Sims to City of Mobile v. Bolden: Have the White Suburbs Commandeered the Fifteenth Amendment? 34 Hastings L.J. 1, 4 (1982) ("The Supreme Court . . has created an intolerable inversion of historical and constitutional priorities.").

277. See South Carolina v. Katzenbach, 383 U.S. 301 (1966). 
the Court's efforts to broaden the application and power of Section 5. In a situation such as this, where a statutory provision has been the subject of years of constant and mutually affirming constitutional dialogue, the Court should not lightly depart from its precedent. The next Section analyzes the specific factors that the Court should weigh when considering such a departure.

\section{Stare Decisis: Reliance of Minority Voters on the Protection of Their Rights}

Stare decisis is the doctrine that the Court should respect and follow the precedent created by its past decisions. The purpose of stare decisis is to promote a settled quality to the law, one that litigants and the public can rely upon. ${ }^{278}$ Clearly there are instances in which a Court overturns itself (or previous Courts), and rightly so. ${ }^{279} \mathrm{But}$ in the interest of stability, predictability, and legitimacy of the Court's holdings, those instances should be rare. Otherwise the risk is that the public will perceive constitutional law to evolve every time one justice leaves the Court and another of a different political persuasion takes her place. In the context of voting rights, the Court has, in an almost unbroken line of cases, consistently upheld the Act and Section 5 since its first review of the legislation in South Carolina v. Katzenbach in I966. In such a situation, where there is no clear notion that those past decisions are so wrong that the Court must disavow them, the Court should not overturn precedent simply because it wishes that earlier Courts had decided cases differently.

In her plurality decision in Planned Parenthood $v$. Casey, ${ }^{280}$ Justice O'Connor discussed the stare decisis considerations that should guide a Court in its decision whether to uphold or overrule a prior decision. According to O'Connor, the Court should

ask whether the rule has proven to be intolerable simply in defying practical workability; whether the rule is subject to a kind of reliance that would lend a special hardship to the consequences of overruling and add inequity to the cost of repudiation; whether related principles of law have so far developed as to have left the old rule no more than a remnant of abandoned doctrine; or whether facts have so changed, or come to be seen so differently, as to have robbed the old rule of significant application or justification. ${ }^{281}$

278. See, e.g., Planned Parenthood v. Casey, 505 U.S. 833, 854-69 (1992) (O’Connor, J., plurality opinion) (discussing the importance of stare decisis).

279. The Court's decision in Brown v. Board of Education, 347 U.S. 483 (1954), overturning the "separate but equal" holding of Plessy v. Ferguson, 163 U.S. 537 (1896), provides the best example. 
In Casey, O'Connor applies this framework to determine whether an earlier decision ${ }^{282}$ should be overruled. Here, an application of those guidelines to the Act and Section 5 demonstrates why neither should be struck down.

The decisions upholding, and even expanding, the Act and its scope have in no sense proven unworkable. As the Court discussed in Boerne, the limitations built into the Act's provisions have served to create a tolerable burden on a discrete class of state laws. ${ }^{283}$ Covered jurisdictions, as the Court noted in Lopez, are not prevented from the passage of voting laws; they must only submit them for preclearance to ensure that those rights protected by the Fourteenth and Fifteenth Amendments will not be gutted. ${ }^{284}$ While the Act's provisions have required judicial assessment of state laws affecting the exercise of the franchise, "the required determinations fall within judicial competence." 285

"[An] inquiry into reliance counts the cost of a rule's repudiation as it would fall on those who have relied reasonably on the rule's continued application." 286 Since 1965, minority voters have relied on the Act as a powerful tool for the federal protection of their voting rights. While discrimination has continued, the ability of Congress to react in a flexible manner to the evolution of voting rights abuses has been important in ensuring minority voters the ability to participate in a meaningful way. For almost four decades, the legislative, executive, and judicial branches have responded to voting discrimination using the provisions of the Act. In some people's minds, the Act has become synonymous with the right to vote itself. Indeed, one recent internet rumor, to which the DOJ felt the need to respond, warned that upon the expiration of the Act's provisions in 2007, Blacks would lose the right to vote unless Congress reauthorized the provisions. ${ }^{287}$ The ability of minorities to participate equally in the most basic democratic function of voting has been facilitated by the Act, Section 5, and the Court's decisions upholding its provisions.

The third inquiry that Justice O'Connor sets out is whether the evolution of legal principle has weakened the foundation of those cases that had upheld the Act. While a number of recent cases have thrown equal protection law into some disarray, there has been neither an explicit, nor implicit, disavowal of those Court cases upholding the Act's provisions. Indeed, the exact opposite is true. In each case that has limited Congress's authority to pass legislation pursuant to its Fourteenth Amendment power, the Court

282. Roe v. Wade, 410 U.S. 113 (1973).

283. City of Boerne v. Flores, 521 U.S. 507, 533 (1997).

284. Lopez v. Monterey County, 525 U.S. 266, $279(1999)$.

285. Planned Parenthood v. Casey, 505 U.S. 833, 855 (1992) (O'Connor, J., plurality opinion).

286. Id.

287. Voting Rights Act Clarification, supra note 241. 
has consistently invoked the Act as the example of legislation that could be constitutionally adopted by Congress to combat discrimination. ${ }^{288}$

The last factor is whether facts have so changed as to undermine the Act's application or justification. As previously discussed in Part III.B.2, the number of objections to voting changes that have been entered before and after the 1982 reauthorization has remained relatively constant. ${ }^{289}$ Even if one were to look at only those objections entered from 1990 until 2002, 340 have been entered by the DOJ. ${ }^{290}$ And given that each decade brings a new round of redistricting and voting changes, the likelihood that voting rights violations will persist is high.

The sum of the inquiry shows that the foundation of those cases upholding the Act and Section 5 has not been weakened in any way. Section 5 has not proved unworkable; indeed, its provisions have provided covered jurisdictions guidance as to permissible voting changes. Additionally, to paraphrase Justice O'Connor, an entire generation of voters has come of age free to assume that their voting rights would be vigorously protected through federal intervention if necessary. No erosion of legal principle or change in facts has made the Act and its provisions any less viable, appropriate, or necessary than they were when first enacted. ${ }^{291}$ Thus, the stronger argument is for affirming the Court's commitment to the Act's protection, not for overruling it.

In addition to the stare decisis analysis, Casey presents another factor that the Court should consider whenever it contemplates overturning cases or striking down laws that are ideologically controversial and politically charged. When a provision such as Section 5 , which has been controversial since its enactment because of the imposition of burdens on states and localities, is under review and when neither the facts underlying the law nor the Court's understanding of them has changed, "the Court could not pretend to be reexamining the prior law with any justification beyond a present doctrinal disposition to come out differently. ..."292 Overruling a prior decision or striking down a law for that reason alone "invites the popular misconception that this institution is little different from the two political branches... . No misconception could do more lasting injury to this Court and to the system of law...."293 Although some justices might harbor serious concern about the impact of the Act and Section 5 on federalism and the separation of powers, ${ }^{294}$ the Court entertains such a rationale

288. See supra note 29.

289. Objections, supra note 195; see also Figure 2, at 807.

290. Objections, supra note 195.

291. Casey, 505 U.S. at 860-61.

292. Id. at 864 .

293. Id.

294. See, e.g., Lopez v. Monterey County, 525 U.S. 266, 293-98 (1999) (Thomas, J., dissenting) (characterizing the obligations imposed by Section 5 on the states as "drastic" and "troubling" and 
for overruling prior decisions in that area at the peril of its own legitimacy. ${ }^{295}$

In sum, assuming that the facts of voting discrimination have not changed, the doctrine of stare decisis applies to uphold Section 5's preclearance requirement. Since the post-reauthorization Section 5 will very likely pass the congruence-and-proportionality test, and since the unique dialogue between the Court and Congress regarding voting rights has served both branches well, the Court should reject any post-reauthorization challenge to Section 5.

\section{CONCLUSION}

The right to vote is foundational in a representative democracy such as the United States; the existence of the right is a threshold for the enjoyment and protection of all other rights and makes it more likely that government will be responsive to community and individual needs and desires. Meaningful access to the ballot box can be one of the few countcrbalances for those communities that feel disempowered or who feel that government officials have not been rcsponsive to them. ${ }^{296}$ Conversely, erecting barricrs to people's exercise of their right to vote-whether thcy are outright barriers to the ability to vote (such as literacy tests or poll taxes) or indirect barriers that dilutc the strength of an individual's vote (such as gerrymandering, annexation, or the creation of majority districts)eliminates the ability to demand accountability and participate in the choosing of those who formulate policy and chart the direction of the

suggesting that he would take a limited view of the provision's scope and application); Holder v. Hall, 512 U.S. 874, 930 n.27 (1994) (Thomas \& Scalia, JJ., concurring) (expressing concern with the scope of Section 5's application).

295. It should be underscored that this section's discussion of stare decisis as support for maintaining Section 5 of the Act is not intended to be read as a wide-sweeping justification for maintaining the status quo in cvery situation. In fact, there are good reasons for thc Court to reconsider the recent decisions striking down antidiscrimination laws. See supra notc 20. These decisions abrogated long-standing judicial precedent regarding the scopc of congressional enforcement power under the Fourteenth Amendment. Indeed, they represent the first time since the era of Reconstruction that the Court has struck down antidiscrimination laws as unsupported by the Fourtcenth Amendment. See Post \& Siegel, supra notc 30, at 443. As discussed supra in Part III.C.3, the Court has developed a framework in Planned Parenthood v. Casey, 505 U.S. 833 (1992), to guide its stare decisis analysis. The Casey framework does not suggest that the recent decisions limiting congressional authority should be shielded from future reconsideration by the Court.

296. This statement assumes, of course, that we are discussing meaningful access to the ballot box in the election of federal government officials (like congressperson, senator, or president) or the election of state officials (like assemblyperson, senator, or governor). However, the elections that are most rclevant and important (and more subject to voting rights abuses) in the local context are those "closer" to home such as the election of school boards, local judges, and water districts. Section 5's importance is no less in these more localized elections. Indeed, one could argue that Section 5's protections arc morc crucial in those local elections than in national or statewide elections sincc changes are more numcrous and subtle in smaller jurisdictions, and thus harder to police, and the winners of local elections are more likcly to wield substantial power and discretion in pcople's day-today lives. 
country. It is therefore essential that the federal government be vigilant in protecting everyone's right to vote.

The authority of Congress to enact provisions intended to combat a long history of racial discrimination in the area of voting is well settled. There is no other example of such an exhaustive congressional record like the one dealing with voting discrimination-especially since Congress's findings have been amplified and supplemented every time it has chosen to reauthorize the Act. Congress's documentation of voting rights abuses together with the enforcement powers contained in the Fourteenth and Fifteenth Amendments allowed the legislature to craft and then pass the Act. Additionally, specific to Section 5, Congress and the DOJ have compiled a record of efforts undertaken by state and local officials in jurisdictions with the longest history of voting rights abuses to circumvent the Act and to undermine minorities' right to vote. Instances of voting rights abuses are not a thing of the past. Indeed, the passage of time has seen the advent of subtler, yet equally effective, methods of undermining minorities' right to vote: Each decade brings a new census and with it, new chances for states and localities to undermine the political voice of minorities; small jurisdictions may be tempted to forego compliance with Section 5 in the hope that the DOJ will not be able to ensure compliance; and the thousands of changes submitted every year underscore the potential for widespread abuse (indeed hundreds of DOJ objections continue to be entered in response to changes submitted).

Given the opportunity for, and examples of, continued abuse of the voting rights of minorities, Congress must reauthorize Section 5's preclearance provisions in 2007. Not only is reauthorization necessary to combat newer species of voting changes that work to undermine minorities' votes, but the extension of preclearance is necessary to ensure that old forms of abuses do not reappear. The expiration of Section 5's provisions would mean that those jurisdictions that had the worst legacy of denying voting rights to their minority citizens would be able to adopt changes to their voting procedures without any oversight. Additionally, as demographic change continues to alter the racial landscape throughout the country and as the voting rights battlc lines are drawn in increasingly local electoral contexts (school board elections, water district elections, local judicial elections) Section 5's protections become even more critical to ensuring that minorities enjoy a meaningful right to vote. Lastly, at a time when voter cynicism and apathy drives voter participation rates to new lows with each election and when there is a retrenchment of conservative politics that many perceive as anti-minority, there is a need for a symbolic and substantive commitment on the part of government to protecting the right to vote for people of color. Congress must heed these factors, as well and others, and extend the life of Section 5 in particular and the Act in 
general. But Congress's extension of the Act would only mark the first stage in the effort to ensure the continued vitality of the Act. Ultimately, it is likely that the Court would be the final arbiter regarding the reauthorization of the legislation.

Given the spate of legal victories won by conservative activist organizations in the last five years there is every reason to assume that any extension of Section 5 would be quickly met by a legal challenge to its constitutionality. And despite the Court's recent pronouncement about Section 5's continued constitutionality in Lopez, decisions in other cases dealing with antidiscrimination law and states' rights ${ }^{297}$ make predicting the outcome of a challenge to the Act after 2007 less than clear or comforting. If the Court were to sustain a challenge to Section 5 and strike down the preclearance provisions, we would likely return to a pre-1965 world in which the rooting out of voting discrimination in those jurisdictions with the longest, and most persistent, pattern of discrimination would be difficult, inefficient, and often, ineffective. The enforcement of minorities' voting rights would return to a piecemeal effort-akin to emptying the ocean, one spoon at a time. The fact that there is a record establishing that jurisdictions are still violating the provisions of the Act means that any return to such a fractured enforcement effort would be substantively and symbolically catastrophic.

The Court should reject any challenge to Section 5 and the Act that might be initiated (now or post-reauthorization). The application of Boerne's congruent-and-proportional test, the interbranch dialogue, and the respect that the Court pays to its own precedent should persuade it to uphold the provisions of the Act. In so doing, the Court would simultaneously make sure that the solutions which Congress chooses to adopt do not exceed the problems the legislature is trying to address while also respecting the Congress's authority to enact laws proteeting people's right to vote. Combating officials' efforts to deny minorities' right to vote has been maddeningly difficult. Section 5 has succeeded because it has worked a radical change, shifting the burden of proof from the victim of discrimination to the discriminator. The Court should recognize the unique role that Section 5 has played in voting rights protection and allow the government to continue to utilize Section 5's provisions in its efforts to combat abuse. 